Article

\title{
Design of a Building-Integrated Photovoltaic System with a Novel Bi-Reflector PV System (BRPVS) and Optimal Control Mechanism: An Experimental Study
}

\author{
Muhammad Adil Khan ${ }^{1}$, Kamran Zeb ${ }^{1,2}$, Waqar Uddin ${ }^{1}$ (D), P. Sathishkumar ${ }^{1}$, \\ Muhammad Umair Ali ${ }^{1}$ (D), S. Hussain ${ }^{1}$, M. Ishfaq ${ }^{1}$, Himanshu ${ }^{1}$, Archana Subramanian ${ }^{1}$ \\ and Hee-Je Kim ${ }^{1}$ * \\ 1 School of Electrical Engineering, Pusan National University, Busandaehak-ro 63beon-gil, Geumjeong-gu, \\ Busan 46241, Korea; engradilee@gmail.com (M.A.K.); kami_zeb@yahoo.com (K.Z.); \\ waqar_dir98@yahoo.com (W.U.); sathishnano2013@gmail.com (P.S.); umairali.m99@gmail.com (M.U.A.); \\ sadamengr15@gmail.com (S.H.); engrishfaq1994@gmail.com (M.I.); himanshuhimanshu820@gmail.com (H.); \\ er.ararchu@gmail.com (A.S.) \\ 2 School of Electrical Engineering and Computer Science, National University of Sciences and Technology, \\ Islamabad 44000, Pakistan \\ * Correspondence: heeje@pusan.ac.kr; Tel.: +82-51-510-2364
}

Received: 29 June 2018; Accepted: 17 July 2018; Published: 18 July 2018

\begin{abstract}
Environment protection and energy saving are the most attractive trends in zero-carbon buildings. The most promising and environmentally friendly technique is building integrated photovoltaics (BIPV), which can also replace conventional buildings based on non-renewable energy. Despite the recent advances in technology, the cost of BIPV systems is still very high. Hence, reducing the cost is a major challenge. This paper examines and validates the effectiveness of low-cost aluminum ( $\mathrm{Al}$ ) foil as a reflector. The design and the performance of planer-reflector for BIPV systems are analyzed in detail. A Bi-reflector solar PV system (BRPVS) with thin film Al-foil reflector and an LLC converter for a BIPV system is proposed and experimented with a $400-\mathrm{W}$ prototype. A cadmium-sulfide (CdS) photo-resistor sensor and an Arduino-based algorithm was developed to control the working of the reflectors. Furthermore, the effect of Al-foil reflectors on the temperature of PV module has been examined. The developed LLC converter confirmed stable output voltage despite large variation in input voltage proving its effectiveness for the proposed BRPVS. The experimental results of the proposed BRPVS with an Al-reflector of the same size as that of the solar PV module offered an enhancement of $28.47 \%$ in the output power.
\end{abstract}

Keywords: building integrated photovoltaics (BIPV); renewable energy; solar; LCC converter; half bridge; bi-reflector solar PV system (BRPVS)

\section{Introduction}

Recently, environmental pollution, global warming, and energy shortage have been generally seen as alarming global issues. The building sector consumes a major proportion of energy. For example, in the European Union, 30-40\% of energy is consumed by the building sectors, that produce $32 \%$ of carbon dioxide emissions [1]. Attention has been given to zero energy buildings to develop future energy saving infrastructures. In this scenario, renewable energy is expected to play an important role. Photo-Voltaic (PV) systems are very attractive choices for production of electric power due to their noiseless and nonpolluting nature. Building Integrated Photo-Voltaic (BIPV) is a new version of the PV system, in which the building is used for installation of PV modules to reduce cost and improve the appearance [2]. In addition to the environmental influences of BIPV, they also reduce 
the long-term cost of the building sector. Compared to a standalone PV system, BIPV does not require any extra land for installation and the cost can be balanced by installing this on the rooftop of the building structure [3]. However, the lower efficiency and higher initial cost make BIPV less practical and difficult to commercialize. Dye-Sensitized Solar Cells (DSSCs) have attracted considerable attention in recent years because of their simple assembly, lightweight, flexibility, economical price of materials, satisfactory photocurrent transformation efficiency, precise energy return time, and tunable optical properties [4]. On the other hand, DSSCs have power conversion efficiency of more than $14 \%$ with a limited active area; the output power decreases with increasing cell effective area of the photoanode [5]. An alternate solution exists to increase the net output power from the PV module to reduce the cost of the system because the initial cost of the PV system is the main hurdle to the widespread use of this technology. The output power can be increased by increasing the incident light on the PV system [6]. The position of the Sun is not fixed to one place because it changes its position from dawn to dusk and also during the entire year, which means that a fixed PV system is inefficient. Therefore, the tracking of single- and dual-axis PV systems are suggested for this purpose [7,8]. On the other hand, such a system has two disadvantages, increase in initial cost and decreased lifetime of the mechanical parts of the PV system. Moreover, such a system also requires extra power supply and motors to move the solar system, which makes the system more complex and increases the size of the PV system, making it unrealistic for commercialization [8,9].

Another way is to reflect the light onto the PV module to increase the efficiency of BIPV systems. This system will increase the sunlight flux intensity per unit area on the BIPV, resulting in an amplified output power, which would allow a decrease in the size and cost of the PV module. With the help of the reflector with a planar shape, solar radiation will increase [10]. The advances in architecture and the artistic structure of buildings with narrow roof spaces has created a challenging situation for the installation of a BIPV system with reflectors and the crowded city has forced planning management to consider the roof and facade [11]. Despite this, installing such a system will make the architecture appear less attractive, which is a notable factor in new solar systems [12]. Moreover, the health concerns for BIPV can be a major disadvantage and a real challenge for BIPV systems. The study predicted a gain in annual output from amorphous Silicon (a-Si) PV modules of up to $25 \%$, considering the latitude of $60^{\circ} \mathrm{N}$ and a specular reflector with a reflectivity of 0.8 [13]. Probst and Roecker reported the advantages of mixing solar collectors for developing a system [14]. The advantage of adding booster reflectors by placing the reflector at a $90^{\circ}$ angle with a crystalline Silicon (c-Si) PV module and varying the inclination of the assembly was explored in [15]. Karlson and Wilson [16] designed the Maximum Reflector Collector (MaReCo) in 2000, which was then modified by Brogren and Karlson [17] from an edge reflector to a parabolic design, which boost the radiations falling on the PV module. On the other hand, not all the increasing radiation was converted to electrical power; some was reflected and some were converted to heat in BIPV module. From such studies, a small amount of heat was absorbed by the cell, which decreased the efficiency of the cell and module. The increase in temperature resulted in a $0.3-0.5 \%$ per $\mathrm{K}$ decrease in efficiency [18]. The increase in temperature in the BIPV system was overcome using a Building Integrated Photo-Voltaic Thermal system (BIPVT) [19]. Using such a system, the efficiency was increased to $30-40 \%$ and two separate collector quantities of space and material were minimized due to hybridization [20]. This choice was more substantial because of the low price and sufficient availability, and these two factors make it more practical. A Concentrated Photo-Voltaic (CPV) system, which applies an optical element, was used to focus the sunlight on the solar cell. Such type of intensified light increased the energy up to some extent [21,22]. Some studies suggested a horizontal arrangement of the reflector with the solar panel [23]. A model of ray tracing to calculate the irradiation rise was proposed [24]. Some used diffuse reflectors, which are a collective view factor and specular reflectance mode [25], whereas others use a 2-D specular reflectance model and experimental data [26]. The non-specular ridged booster reflector increased the output by $8 \%$ [27]. Although Mirror-Augmented Photo-Voltaic (MAPV) is low cost, it produces non-uniformity in irradiance, which is overcome by optimizing the system properly 
to maximize the annual power production. The uniformity in a PV system is the primary objective of the system, but the PV module is not ideal for MAPV because of its non-uniformity [28]. A different method was suggested by Van Dijk et al. for power conversion improvement. The solar module has a glass layer with a lens array on the top and a reflector on bottom side [29]. A reflector perpendicular to the PV panel with a width 2.7 times the panels obtains a result of 1.5 at solar noontime and was used keeping in view weather conditions of Tokyo, Japan [30]. Khan et. al. studied three different (i.e., flat mirror, spherical mirror and $\mathrm{Al}$ foil) reflector materials for studying high-performance materials and used a variety of cooling techniques to enhance the performance of existing PV systems [31].

Effective power conditioning for BIPV is crucial. In common practice, the boost DC-DC converter is used to increase the PV voltage and track the maximum point of the PV output power in real time. Considering that switching of semiconductor devices occurs at high currents, the efficiency of these converters is low at high frequencies because of the hard switching [32-36]. On the other hand, at low frequencies, the size and cost of the magnetic components and the capacitor would be high. Furthermore, the parasitic capacitance of the PV modules to the ground might cause leakage currents due to the lack of isolation in conventional power conversion topologies [37]. To handle these problems, a DC-DC LLC resonant converter was presented [38,39]. LLC converters have been utilized broadly in various DC converters as a result of their similar zero voltage Switching (ZVS) for the essential MOSFETs and zero current Switching (ZCS) for optional diodes, which enable them to achieve high proficiency and power thickness $[40,41]$. Typically, pulse width switching frequency modulation techniques is utilized as a part of LLC resonant converters to standardize the output current and voltage, yet the non-direct highlights of the input voltage make it difficult for ordinary linear control systems to accomplish the normal execution and a hybrid control scheme has been introduced for the purpose of switching [42,43].

Based on a literature survey and discrepancy available in existing solutions to enhance the PV module power for a BIPV system, this study evaluated the Al-foil sheet and LLC converter-based Bi-Reflector PV System (BRPVS). A reflector system was designed to enhance the output power, and a hybrid control scheme of a half-bridge LLC resonant converter is proposed for a wide input range application and medium power applications. The objective of this research is to design and briefly discuss a novel reflector system (BRPVS) its operation and possible outcomes. This study conducted real-time experiments to examine the performance of BRPVS and developed an algorithm to control the working of the BRPVS. Its effects on the output power were examined and its optimal control way of operation was defined. Moreover, an optical and thermal model was also evaluated. A detailed description of the system is provided in Section 2. The remainder of the manuscript is arranged as follows. Section 2 presents a detailed overview of the proposed system along with component required to design the BRPVS system. Experimental arrangements of the designed system are discussed in Section 3. Results for experimental study are discussed in Section 4 while Section 5 summarizes the conclusion of this study.

\section{System Components and Development}

\subsection{An Overview of Proposed BRPVS}

Figure 1 presents an overview of the proposed solution. The overall system was comprised of a Bi-reflector system (BRS), whose output is given to a half-bridge resonant LLC converter. Movement of the BRDF (Bidirectional Reflectance Function) system is achieved using an Arduino based automatic stepper motor and a CdS sensor arrangement, whose working was controlled by an algorithm developed in Section 2.2.2. The output power of the LLC converter was transferred to the energy storage system (ESS) to supply electric power to the building via an inverter and power distribution system. A detail description of the components of the system is provided in this section. 


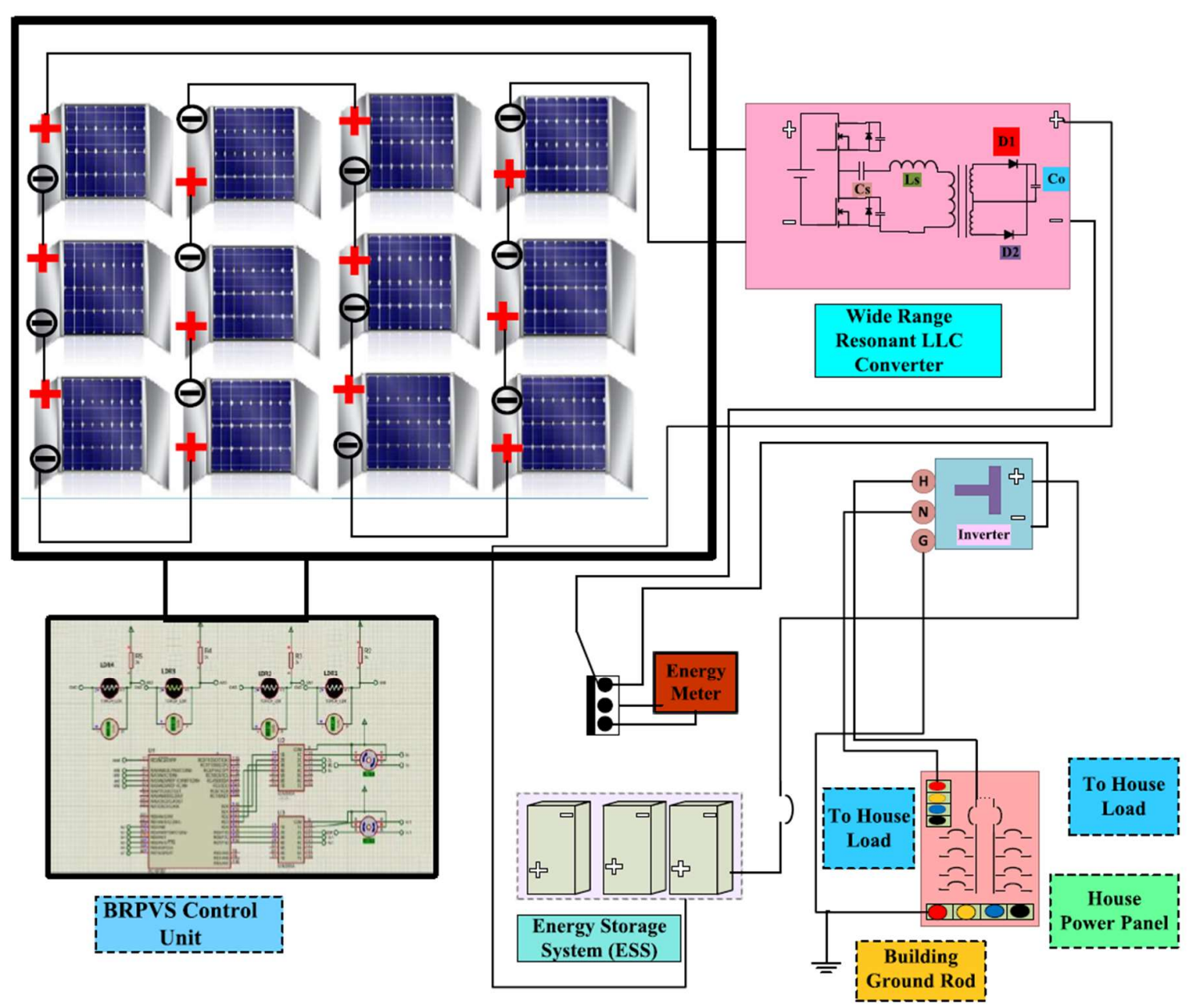

Figure 1. An overview Proposed BRPVS with its mandatory components (i.e., BRS, LLC converter, inverter, Energy storage system, distribution, and control unit).

\subsection{Components of Designed BRPVS System for BIPV}

A detailed overview of the components of the proposed system and their corresponding operating mechanisms is described below.

\subsubsection{Wide Range Medium Power LLC Converter}

Figure 2 shows the proposed topology of a wide range of LLC resonant converters designed for a wide range of input voltage variations. As the BIPV system undergoes voltage fluctuations, the design topology provides a fixed output voltage despite input voltage variations. The main structure of the LLC converter starts with a voltage divider, and in this design the load and resonant tank act as a voltage divider. The half-bridge LLC resonant converter topology is formed with the help of an input bridge. The resonant tank system is connected to the load, rectifier system, and filter network. 


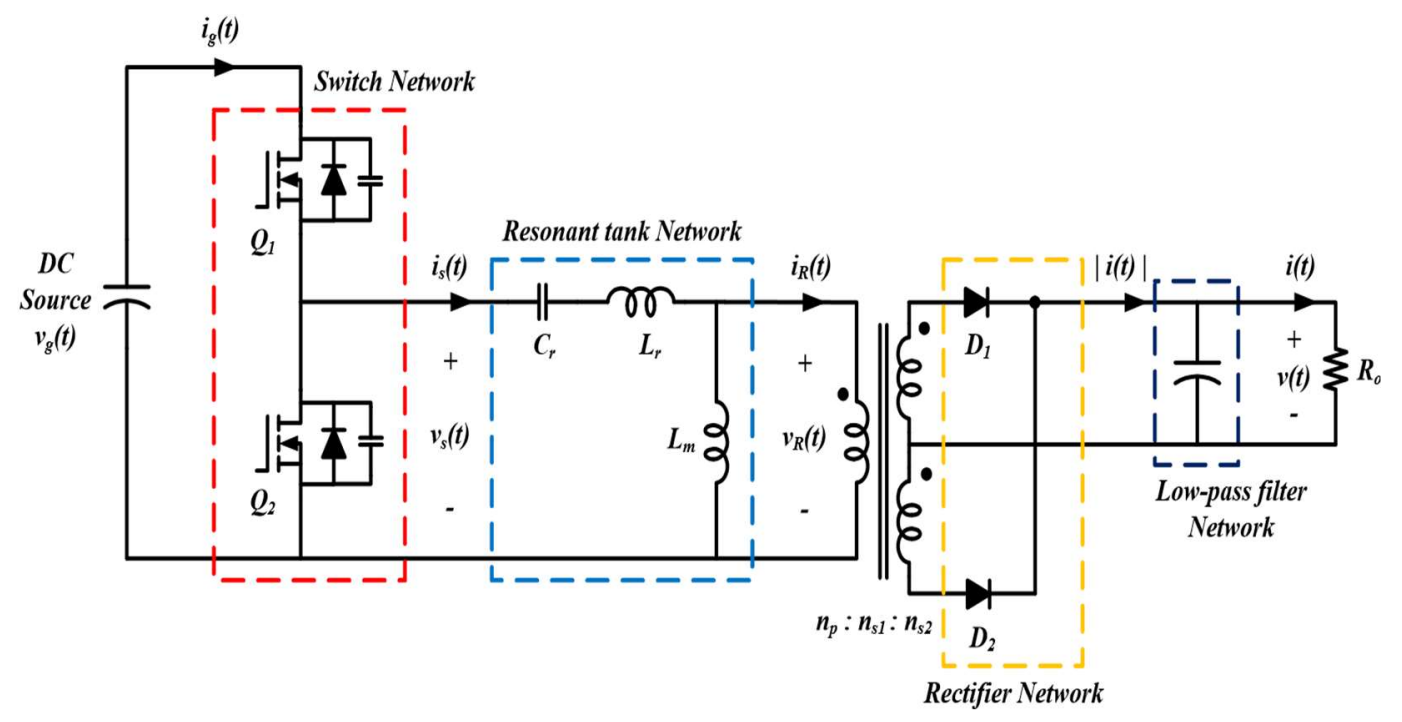

Figure 2. Half-bridge Converter Topology for BRPVS.

Figure 3 demonstrates that a square wave is produced by the switch network having frequency $\mathrm{f}_{\mathrm{s}}=\omega_{\mathrm{s}} / 2 \pi$. With the resonant L-C network present in the topology of the converters, generates sinusoidal the current and voltage are using each frequency cycle and hence sinusoidal approximation is suitable to examine the characteristics and parameter determination of the converter.

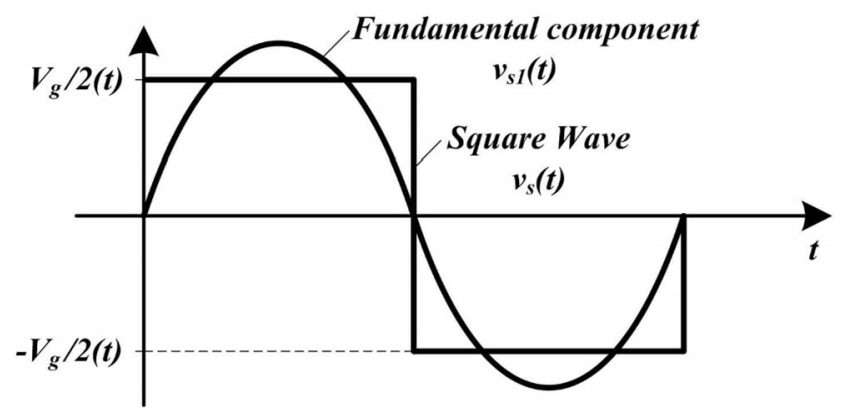

Figure 3. Output voltage of switch network along with its fundamental component.

The switching network, which produces a fundamental and odd harmonic of square wave voltage. Fundamental component $\mathrm{v}_{\mathrm{S} 1}(t)$ can be calculated using Equation (1) [44].

$$
\mathrm{v}_{\mathrm{S} 1}(t)=\frac{2 \mathrm{~V}_{\mathrm{g}}}{\pi} \sin \left(\omega_{\mathrm{s}} t\right)=\mathrm{v}_{\mathrm{s} 1} \sin \left(\omega_{\mathrm{s}} t\right)
$$

where $V_{g}$ shows amplitude of the input square wave. Resonant output current denoted by $i_{R}$ is defined by Equation (2) a with peak amplitude $\left(\mathrm{I}_{\mathrm{R} 1}\right)$ and phase shift $\left(\theta_{\mathrm{R}}\right)$

$$
\mathrm{i}_{\mathrm{R}}=\mathrm{I}_{\mathrm{R} 1} \sin \left(\omega_{\mathrm{s}} t-\theta_{\mathrm{R}}\right)
$$

The rectifier input voltage $\left(\mathrm{V}_{\mathrm{R}}(t)\right)$ well be similar to its fundamental component $\left(\mathrm{V}_{\mathrm{R} 1}\right)$ and is given be below relation (i.e., Equation (3))

$$
\mathrm{V}_{\mathrm{R} 1}=\frac{4 \mathrm{~V}}{\pi} \sin \left(\omega_{\mathrm{s}} t-\theta_{\mathrm{R}}\right)
$$


As capacitor does not allow DC current to pass through it, steady-state load current $\mathrm{i}(t)$ and DC component (I) of rectifier input current are equal expressed by Equation (4).

$$
\mathrm{I}=\frac{2}{\mathrm{~T}_{\mathrm{s}}} \int_{0}^{\frac{\mathrm{T}_{0}}{2}} \mathrm{I}_{\mathrm{R} 1} \mid \sin \left(\omega_{\mathrm{s}} t-\theta_{\mathrm{R}} \mid \mathrm{dt}=\frac{2}{\pi} \mathrm{I}_{\mathrm{R} 1}\right.
$$

The effective resistive load $\left(R_{e}\right)$ of the RC-tank can be evaluated as ratio of $V_{R 1}(t)$ and $I_{R 1}(t)$ given by Equation (5).

$$
\mathrm{R}_{\mathrm{e}}=\frac{\mathrm{V}_{\mathrm{R} 1}(t)}{\mathrm{I}_{\mathrm{R} 1}(t)}
$$

The transfer function $(\mathrm{H}(s))$ of the designed LLC converter is given utilizing Equation (6).

$$
\mathrm{H}(s)=\frac{s \mathrm{~L}_{\mathrm{m}} \| \mathrm{R}_{\mathrm{e}}}{s \mathrm{~L}_{\mathrm{r}}+\frac{1}{s \mathrm{C}_{\mathrm{r}}}+s \mathrm{~L}_{\mathrm{m}} \| \mathrm{R}_{\mathrm{e}}}
$$

The voltage gain (M) i.e., transfer function magnitude, is given by Equation (7).

$$
M=\frac{\left(\frac{f}{f_{r}}\right)^{2}(m-1)}{\sqrt{\left(\frac{f^{2}}{f_{p}^{2}}-1\right)^{2}+\left(\frac{f}{f_{r}}\left(\frac{f^{2}}{f_{r}^{2}}-1\right)(m-1)\right)^{2}}}
$$

where $\mathrm{L}_{\mathrm{p}}=\mathrm{L}_{\mathrm{m}}+\mathrm{L}_{\mathrm{r}}, \mathrm{m}=\frac{\mathrm{L}_{\mathrm{p}}}{\mathrm{L}_{\mathrm{r}}}, \mathrm{Q}=\frac{1}{\mathrm{R}_{\mathrm{e}}} \sqrt{\frac{\mathrm{L}_{\mathrm{r}}}{\mathrm{C}_{\mathrm{r}}}}, \mathrm{f}_{\mathrm{r}}=\frac{1}{2 \pi \sqrt{\mathrm{L}_{\mathrm{r}} C_{\mathrm{r}}}}, \mathrm{f}_{\mathrm{p}}=\frac{1}{2 \pi \sqrt{\mathrm{L}_{\mathrm{p}} C_{\mathrm{p}}}}$.

According to the mode of operation, the DC characteristics of the LLC resonant converter can be divided into three regions, as shown in Figure 4. In region 1, the converter works in a similar manner to SRC. In this region, $\mathrm{L}_{\mathrm{m}}$ does not resonate with the resonant capacitor, $\mathrm{C}_{\mathrm{r}}$; it acts as a load of the series resonant tank when it is clamped by the output voltage. The LLC resonant converter can operate under the no load condition without the penalty of a very high switching frequency with a passive load. In addition, with a passive load, $\mathrm{L}_{\mathrm{m}}, \mathrm{ZVS}$ could be ensured for any load condition.

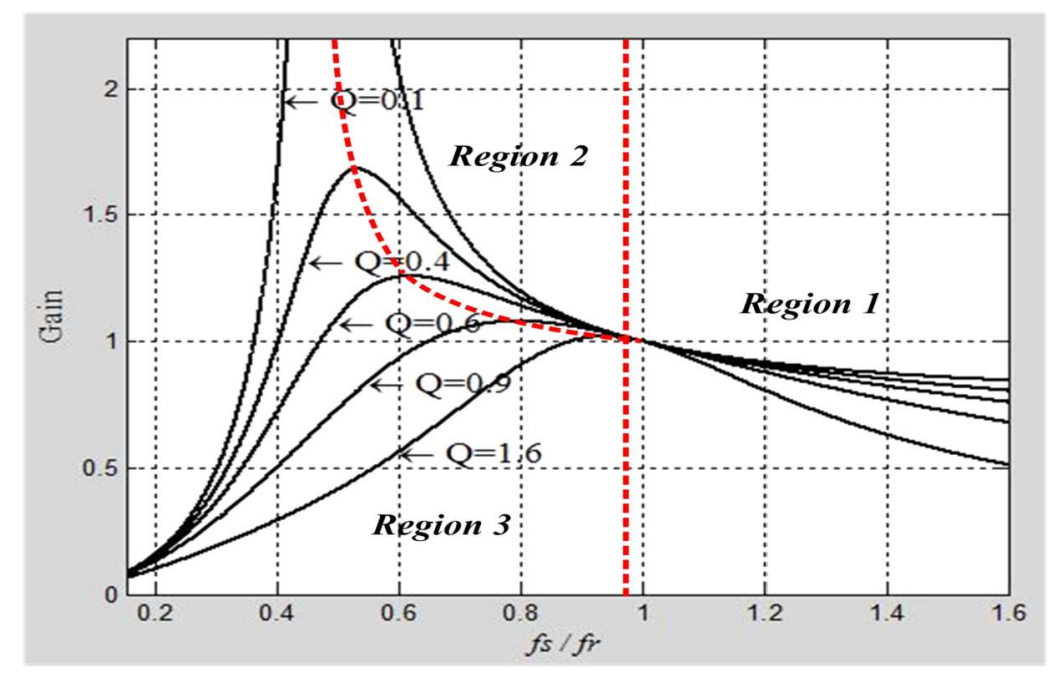

Figure 4. Operation regions for Half bridge LLC converter [43].

In region 2, the converter operation is more complicated. At the beginning $\mathrm{L}_{\mathrm{r}}$ is resonant with $\mathrm{C}_{\mathrm{r}}$ and $\mathrm{L}_{\mathrm{m}}$ is clamped by the output voltage. As the $\mathrm{L}_{\mathrm{r}}$ current reaches the same level as the $\mathrm{L}_{\mathrm{m}}$ current, the $L_{r}$ and $C_{r}$ resonance is stopped, and $L_{m}$ starts participating. As the LLC resonant converter acts as a multi-resonant converter, the resonant frequency is different in different intervals of time 
because of resonant process between $L_{m}+L_{r}$ with $C_{r}$. The designed operating region is region 2 and precautionary measure should be made to prevent the converter from entering region 3 . For resonant converter output voltage control, controlling of switching frequency is used mostly to change the DC gain of the resonant tank. If the input voltage of the resonant converter changes or the load fluctuates, the resonant change impedance of the tank changes according to the switching frequency change of the control hybrid control system that adjusts the output voltage by changing the switching frequency. The net change in switching frequency is made according to the design of the resonant tank and consequently relates to the load conditions and the input voltage range.

\subsubsection{Al-Foil Based Bi Reflector System (Al-BRS)}

Aluminum foil, as an inexpensive reflective material, was used for economic and high output power solar PV systems, which is a very thin sheet of aluminum, ranging from approximately $0.006 \mathrm{~mm}$ to the upper ISO defined the limit of $0.2 \mathrm{~mm}(200 \mu \mathrm{m})$. For the protection of Al layer from oxidation aluminum oxide layer is placed on the top of it. As per requirement of thickness, aluminum foil is rolled with the help of beta radiation sensor. The common properties of Al foil are shown in Table 1.

Table 1. Properties of Al Foil sheets used for BRS [45].

\begin{tabular}{cc}
\hline Density & $2.7 \mathrm{~g} / \mathrm{cm}^{3}$ \\
Melting point & $660{ }^{\circ} \mathrm{C}$ \\
Al foil specific weight & $6.35 \mu \mathrm{m}$ foil weighs $17.2 \mathrm{~g} / \mathrm{m}^{2}$ \\
Melting point & $660{ }^{\circ} \mathrm{C}$ \\
Electrical resistivity & $26.5 \mathrm{n} \Omega \mathrm{m}$ \\
Electrical conductivity & $64.94 \%$ IACS (IACS: International Annealed Copper Standard) \\
Thermal conductivity & $235 \mathrm{~W} / \mathrm{m} \cdot \mathrm{K}$ \\
Thickness & Foil is defined as measuring less than $0.2 \mathrm{~mm}(<200 \mu \mathrm{m})$ \\
\hline
\end{tabular}

Figure 5 shows an overview of a BRS with an Al reflector with attached PV modules with detailed electrical and optical models given below.

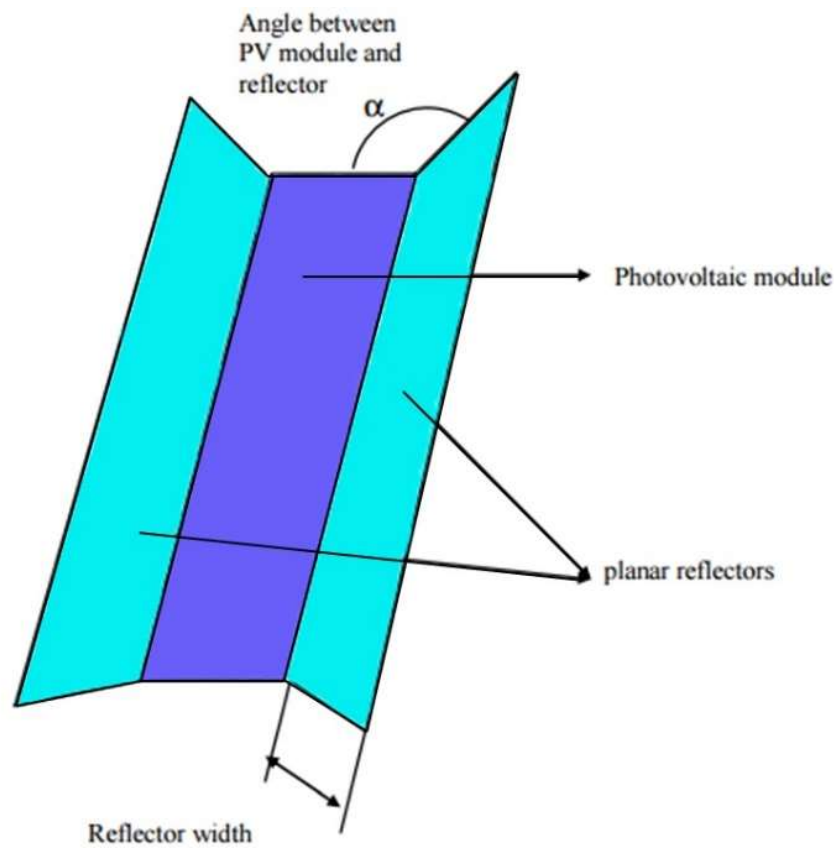

Figure 5. An overview of Al- foil based Bi reflector system (Al-BRS). 


\section{Electrical Modeling}

For modeling of BRS, an equivalent electric circuit is developed, as depicted in Figure 6. The equivalent model consists of a current source for a solar cell with a photocurrent $\left(\mathrm{I}_{\mathrm{L}}\right)$ with a pn junction diode, a parallel resistor $\left(R_{s h}\right)$ and a series resistor $\left(R_{s}\right)$.

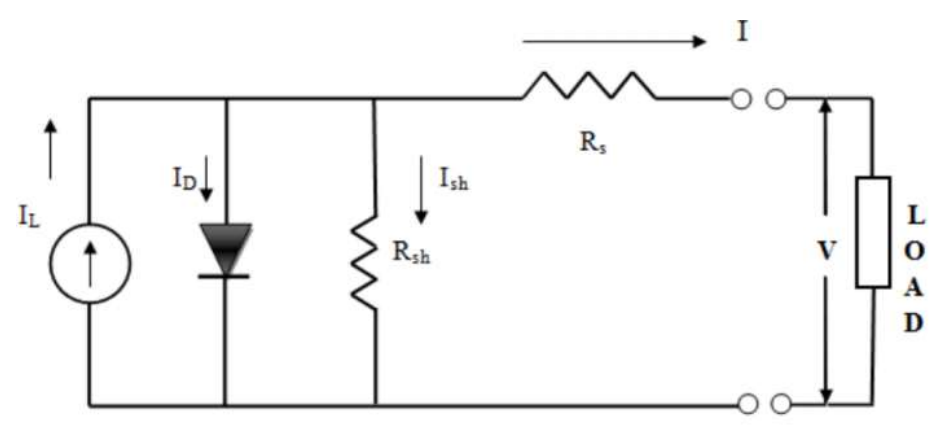

Figure 6. Equivalent circuit for an Al-BRS.

Solar irradiance and constant temperature and solar irradiance, the V-I characteristics of the model which has been proposed can be given using the Equation (8):

$$
\mathrm{I}=\mathrm{I}_{\mathrm{L}}-\mathrm{I}_{\mathrm{O}}\left[\exp \left(\frac{\mathrm{V}+\mathrm{R}_{\mathrm{s}}}{\mathrm{a}}\right)-1\right]-\frac{\mathrm{V}+\mathrm{R}_{\mathrm{s}}}{\mathrm{R}_{\mathrm{sh}}}
$$

Important parameters $\left(\mathrm{I}_{\mathrm{L}, \mathrm{ref}}, \mathrm{I}_{\mathrm{O}, \text { ref, }}, \mathrm{R}_{\mathrm{s}, \text { ref }}, \mathrm{R}_{\mathrm{sh} \text {,ref }}\right.$ and $\left.\mathrm{a}_{\mathrm{ref}}\right)$ for modeling PV module with BRPVS can be estimated by using conditions in Table 2 [46].

Table 2. BRS electrical modeling, conditions used to evaluate important parameters.

\begin{tabular}{cc}
\hline At short circuit & {$[\mathrm{dI} / \mathrm{dV}]_{\mathrm{sc}}=-1 / \mathrm{R}_{\mathrm{sh}, \mathrm{ref}}$} \\
At open circuit voltage & $\mathrm{I}=0, \mathrm{~V}=\mathrm{V}_{\mathrm{oc}, \text { ref }}$ \\
At short circuit current & $\mathrm{I}=\mathrm{I}_{\mathrm{sc}, \mathrm{ref}}, \mathrm{V}=0$ \\
At the maximum power point & $\mathrm{I}=\mathrm{I}_{\mathrm{mp}, \mathrm{ref}}, \mathrm{V}=\mathrm{V}_{\mathrm{mp}, \text { ref }}$ \\
At the maximum power point & {$[\mathrm{dI} / \mathrm{dV}]_{\mathrm{sc}}=0$} \\
\hline
\end{tabular}

Applying the condition defined in Table 2 to Equation (8), Equations (9)-(13) are derived [3]:

$$
\begin{aligned}
& \mathrm{I}_{\mathrm{L}, \text { ref }}=\mathrm{I}_{\mathrm{o}, \text { ref }}\left[\exp \left(\frac{\mathrm{V}_{\mathrm{oc}, \text { ref }}}{\mathrm{a}_{\text {ref }}}\right)-1\right]-\frac{\mathrm{V}_{\mathrm{oc}, \text { ref }}}{\mathrm{R}_{\mathrm{sh}, \text { ref }}} \\
& I_{s c, \text { ref }}=I_{L, \text { ref }}-I_{o, \text { ref }}\left[\exp \left(\frac{I_{s c, \text { ref }} R_{s, \text { ref }}}{a_{\text {ref }}}\right)-1\right]-\frac{I_{s c, \text { ref }} R_{s, \text { ref }}}{R_{\text {sh, ref }}} \\
& I_{m, \text { ref }}=I_{L, \text { ref }}-I_{o, \text { ref }}\left[\exp \left(\frac{V_{m p, \text { ref }}+I_{m p, \text { ref }} R_{s, \text { ref }}}{a_{\text {ref }}}\right)-1\right]-\frac{V_{m p, \text { ref }}+I_{m p, \text { ref }} R_{s, \text { ref }}}{R_{\text {sh,ref }}} \\
& {\left[\frac{\mathrm{dI}}{\mathrm{dV}}\right]_{\mathrm{sc}} \cong-\frac{1}{\mathrm{R}_{\mathrm{sh}, \mathrm{ref}}}} \\
& \frac{I_{m, \text { ref }}}{V_{m p, \text { ref }}}=\frac{\left(\frac{I_{\text {orref }}}{a_{\text {ref }}}\right) \exp \left(\frac{V_{m p, \text { ref }}+I_{m p, \text { ref }} R_{s, \text { ref }}}{a_{\text {ref }}}\right)+\frac{1}{R_{\text {sh,ref }}}}{1+\left(\frac{I_{o, \text { ref }} R_{\mathrm{s}, \text { ref }}}{a_{\text {ref }}}\right) \exp \left(\frac{V_{m p, \text { ref }}+I_{\text {mp,ref }} R_{s, \text { ref }}}{a_{\text {ref }}}\right)+\frac{R_{s, \text { ref }}}{R_{\text {sh,ref }}}}
\end{aligned}
$$

Maximum power output (MPP), current $\left(\mathrm{I}_{\mathrm{mp}}\right)$ and voltage $\left(\mathrm{V}_{\mathrm{mp}}\right)$ are related using below listed equation:

$$
\mathrm{P}_{\mathrm{mp}}=\mathrm{I}_{\mathrm{mp}} \mathrm{V}_{\mathrm{mp}}
$$


Temperature dependency of maximum power point efficiency is a very important aspect when we are dealing with performance of PV module written in below equation:

$$
\eta_{\mathrm{mp}}=\frac{\mathrm{I}_{\mathrm{mp}} \mathrm{V}_{\mathrm{mp}}}{\mathrm{G}_{\mathrm{T}} \mathrm{A}_{\mathrm{m}}}
$$

Optical Modeling

Using the traditional approach of optical geometry, the total irradiance $\left(\mathrm{S}_{\text {tot }}\right)$ absorbed into the BRPVS system can be easily predicted. Total solar radiation $\left(\mathrm{S}_{\mathrm{tot}}\right)$ is the sum of the direct solar radiation $\left(\mathrm{S}_{\mathrm{d}}\right)$ on the solar panel, the ground reflected radiations $\left(\mathrm{S}_{\mathrm{g}}\right)$, the sky diffusion radiations $\left(\mathrm{S}_{\mathrm{SK}}\right)$, the right reflector radiation $\left(S_{\text {reflR }}\right)$ to the surface of the PV panel with a tilted plane angle, $\alpha 1$, and radiation reflected from the left reflector $\left(\mathrm{S}_{\text {reflL }}\right)$ to the PV panel with a tilted plane angle $\alpha 2$ [47]:

$$
\mathrm{S}_{\text {tot }}=\mathrm{S}_{\mathrm{d}}+\mathrm{S}_{\mathrm{g}}+\mathrm{S}_{\mathrm{sk}}+\mathrm{S}_{\text {reflR }}+\mathrm{S}_{\text {reflL }}
$$

We used a reflector for PV system to model the solar system for BRDF [29]. The analysis method of integrative in which irradiation to point differential for PV module represented by $(\mathrm{dx})$ from each differential scattering element on the reflector in (dy) to direction of $\mathrm{dx}$ has been presented [30]. So, in two dimension that is $\mathrm{x}$ and $\mathrm{y}$-axis, integration is performed to show the solar irradiation on module surface. The module in which energy incident $\left(\mathrm{E}_{\mathrm{r}}^{\mathrm{i}}\right)$ is impacting plane reflector at point $\mathrm{dx}$ as shown in Equation (17).

$$
\mathrm{E}_{\mathrm{r}}^{\mathrm{i}}=\mathrm{E}_{\mathrm{p}} \cos \left(\theta^{\prime}\right) \mathrm{dydz}
$$

Through the differential angle $\left(\mathrm{E}_{\mathrm{ref}}\right)$, reflected radiant intensity per unit depth and radiant intensity per unit depth that strikes the surface of the module $\left(E_{m}\right)$ as shown in Equations (18) and (19) respectively [48].

$$
\begin{gathered}
\mathrm{E}_{\mathrm{ref}}=\mathrm{E}_{\mathrm{r}}^{\mathrm{i}} \operatorname{BDRF}\left(\theta, \theta^{\prime}\right) \rho \\
\mathrm{E}_{\mathrm{m}}=\mathrm{E}_{\mathrm{ref}} \mathrm{d} \theta
\end{gathered}
$$

Equation (20) shows the angle of incidence $(\theta)$ of the differential ray onto the surface of the module and the distance that the ray has travelled.

$$
\begin{gathered}
\mathrm{d} \theta=\frac{\mathrm{dyc} \cos (\beta)}{\mathrm{r}} \\
\operatorname{BDRF}\left(\theta, \theta^{\prime}\right)=\frac{\mathrm{D}\left(\theta, \theta^{\prime}\right)}{\int_{-\frac{\pi}{2}}^{\frac{\pi}{2}} \mathrm{D}\left(\theta, \theta^{\prime}\right) \mathrm{d} \theta}
\end{gathered}
$$

Equation (22) can be obtained from Equations (17)-(21) and integrated with characteristic dimensions, and multiplied by the depth of the module $\left(\mathrm{A}_{\text {module }}\right)$ and the irradiance $\left(\mathrm{W} / \mathrm{m}^{2}\right)$ that is on the surface of the module due to reflection $\left(\mathrm{G}_{\mathrm{m}}^{\mathrm{i}}\right)$ can be calculated using Equation (22):

$$
\mathrm{G}_{\mathrm{m}}^{\mathrm{i}}=\frac{\mathrm{G}_{\mathrm{p}} \rho}{\mathrm{A}_{\mathrm{m}}} \int_{0}^{\mathrm{L}_{\mathrm{sect}}} \int_{\mathrm{L}_{\mathrm{m}, \min }}^{\mathrm{L}_{\mathrm{m}, \max }} \operatorname{BDRF}\left(\theta, \theta^{\prime}\right) \cos \left(\theta^{\prime}\right) \frac{\cos (\beta)}{\mathrm{r}} \mathrm{dxdy}
$$

where $\rho$ is surface reflectivity, $\mathrm{A}_{\mathrm{m}}$ module area, and $\theta^{\prime}$ is the angle between the incoming ray and reflector surface

\section{Control Mechanism}

A motorized BRPVS system can be designed by studies done on the bases of the experiment in Section 4. This is an optional control mechanism to obtain greater efficiency. The system was designed with Arduino, Stepper motor, Stepper motor driver, reflectors, Cds/sensors, and power 
supply. Connecting the Stepper motor with Arduino requires a proper connection and wiring pattern using the driver circuits. Figure 7 gives an overview of a motorized BRPVS.

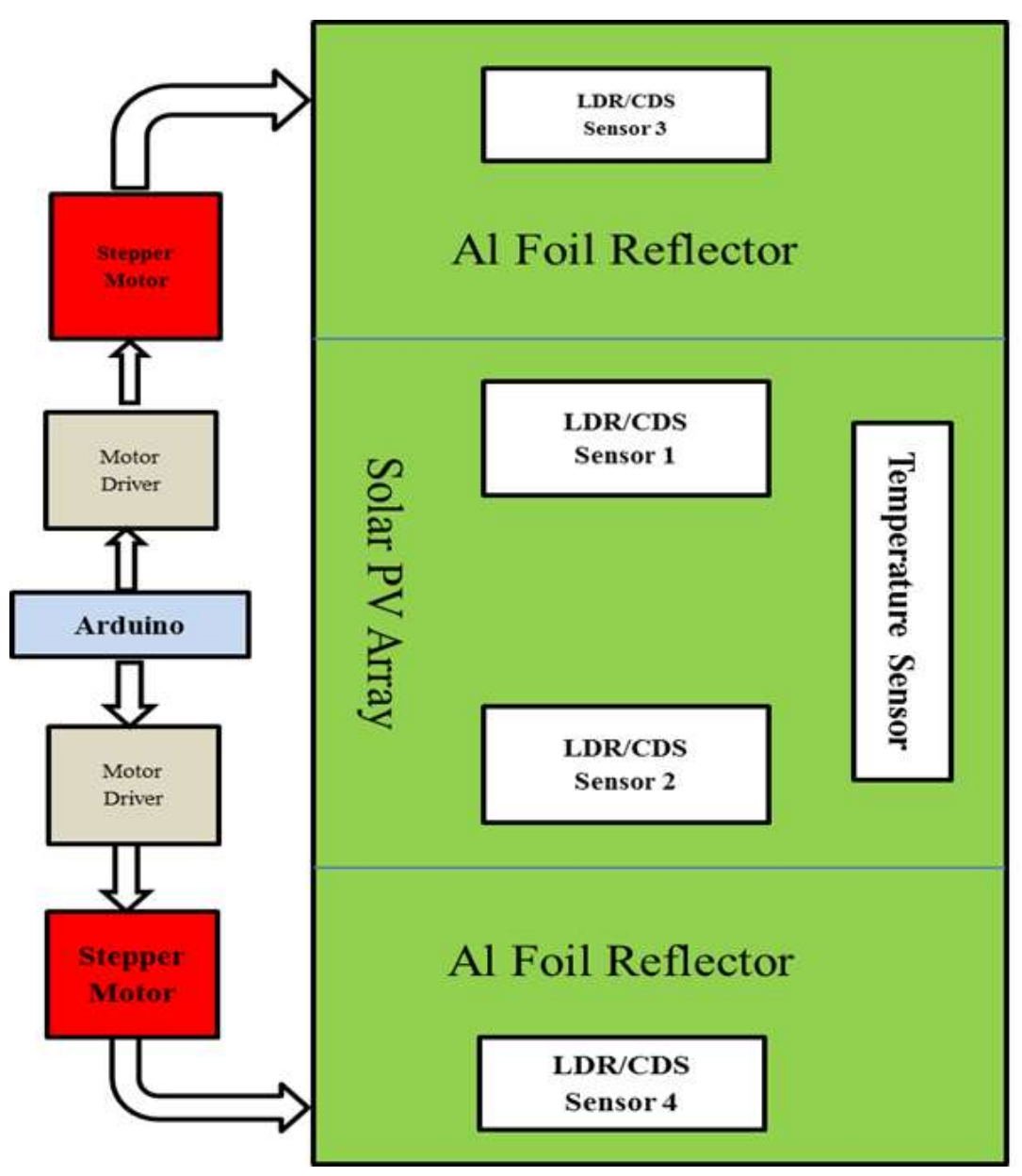

Figure 7. Scheme for control and hardware implementation of Al-BRS.

Figure 8. shows a controlled algorithm for movement of BRPVS. The movement of the reflector is controlled by the CdS sensors placed on the reflectors and solar panel using the controlled algorithm shown in Figure 8. This system is designed with four light-dependent resistors. The resistance of the LDR /CDS sensor varies with light. In the morning, when the amount of light on the right reflector is greater than the left reflector resistance, and the resistance LDR/CDS of the right reflector $\left(R_{C d S(R)}\right)$ is less than the left $\left(\mathrm{R}_{\mathrm{CdS}(\mathrm{L})}\right)$, the Arduino program compares these values and moves the stepper motor of the right reflector at the given optimal angle or tilt $\left(\theta_{\mathrm{TL}}\right)$ when there is shade on the solar panel, i.e., the LDR placed on the right side of the panel resistance $\left(\mathrm{R}_{\mathrm{CdS}(\mathrm{PVR})}\right)$ is no more than the normal bright light operating range $\left(\mathrm{R}_{\mathrm{th}}\right)$. In the afternoon, the resistances of the LDR/CDS right and left sensor are equal and the stepper motor of both reflectors moves focusing light on the solar panel. In the evening, when the amount of light on the left reflector is more than that on the right reflector resistance of the LDR/CDS of the right reflector, the again Arduino program compares these values and moves the stepper motor of the left reflector at the given optimal angle or tilt when there is shade on the solar panel, i.e., the LDR placed on the left side of the panel ( $\left.\mathrm{R}_{\mathrm{CdS}(\mathrm{PVL})}\right)$ is no greater than the normal bright light operating range. Compared to conventional tracing, which requires continuous tracking and movement of the entire Solar PV solar series and parallel array structure, the proposed BRPVS needs to adjust the movement of the reflector only three times per day, i.e., morning, afternoon, and evening. Moreover, this movement of reflectors is an optional feature to enhance the efficiency to a large extent. 


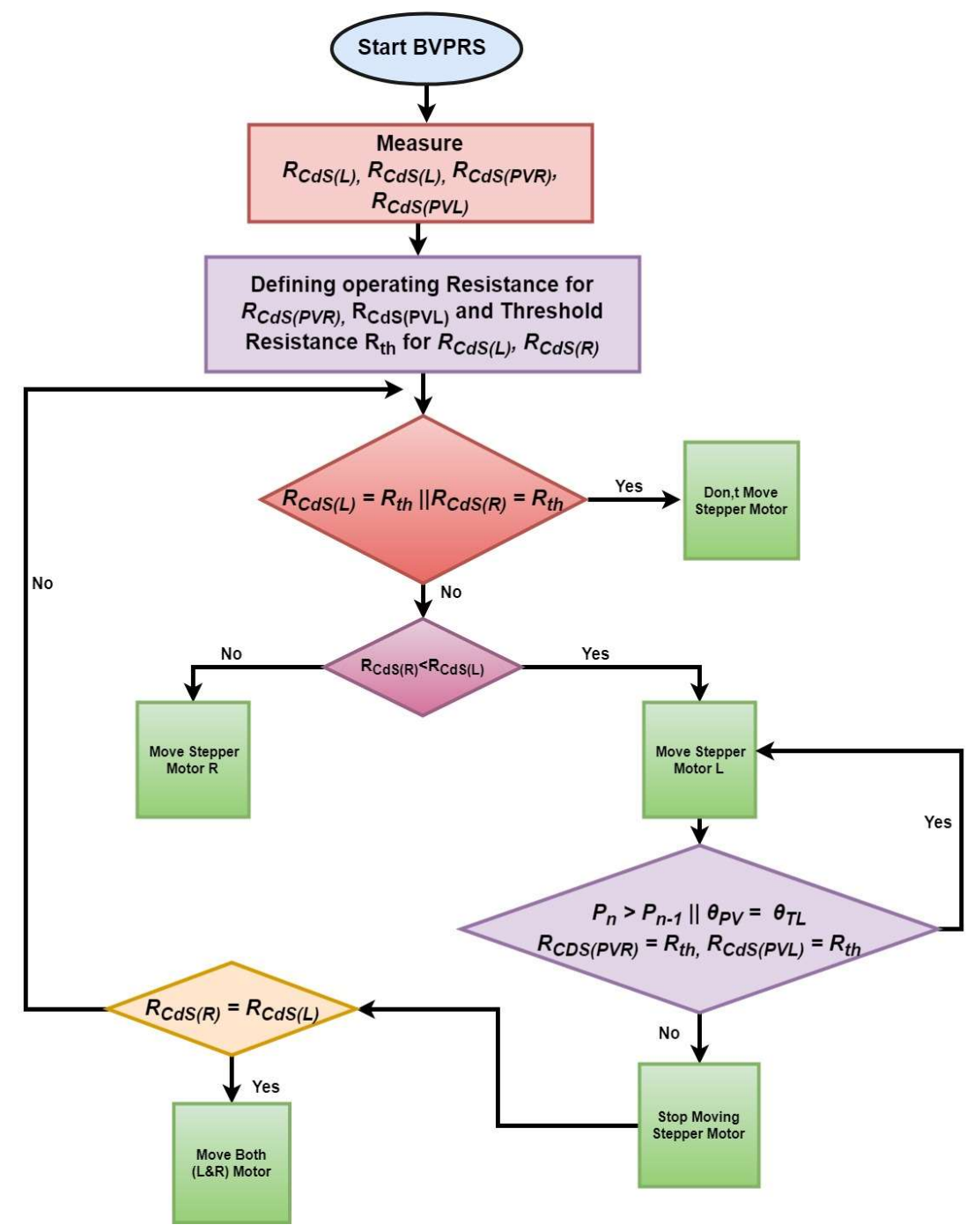

Figure 8. Flowchart explaining control algorithm for operating BRS.

\subsubsection{Inverter (Full-Bridge)}

Half and full bridge are common inverter topologies. The full-bridge (FB) of the inverter is comprised of two legs; switching of the switches makes it possible to prevent a short circuit at the DC input. Switching is carried out in such a way that the upper leg is complementary to the lower leg of the same bridge. In addition, a dead time is introduced between switching to ensure the protection of switches from a short circuit.

Unlike the half-bridge (HB), the output voltage is double that of FB having the same input voltage. Therefore, the current will be half in the FB inverter compared to that of $\mathrm{HB}$ inverter having the same power rating. Figure 9 shows the FB inverter of single-phase switching states.

The carrier-based modulation technique of the PWM controller is the most widely used and effective method. In this type of method, the carrier signal is modulated with the reference signal, and a mostly triangular shape wave is used as the carrier and sinusoidal signal for the reference signal. This technique is quite simple and provides an effective response for inverters.

Figure 9 presents a circuit with an inductor and capacitor along with parameters as a LC lowpass filter. 


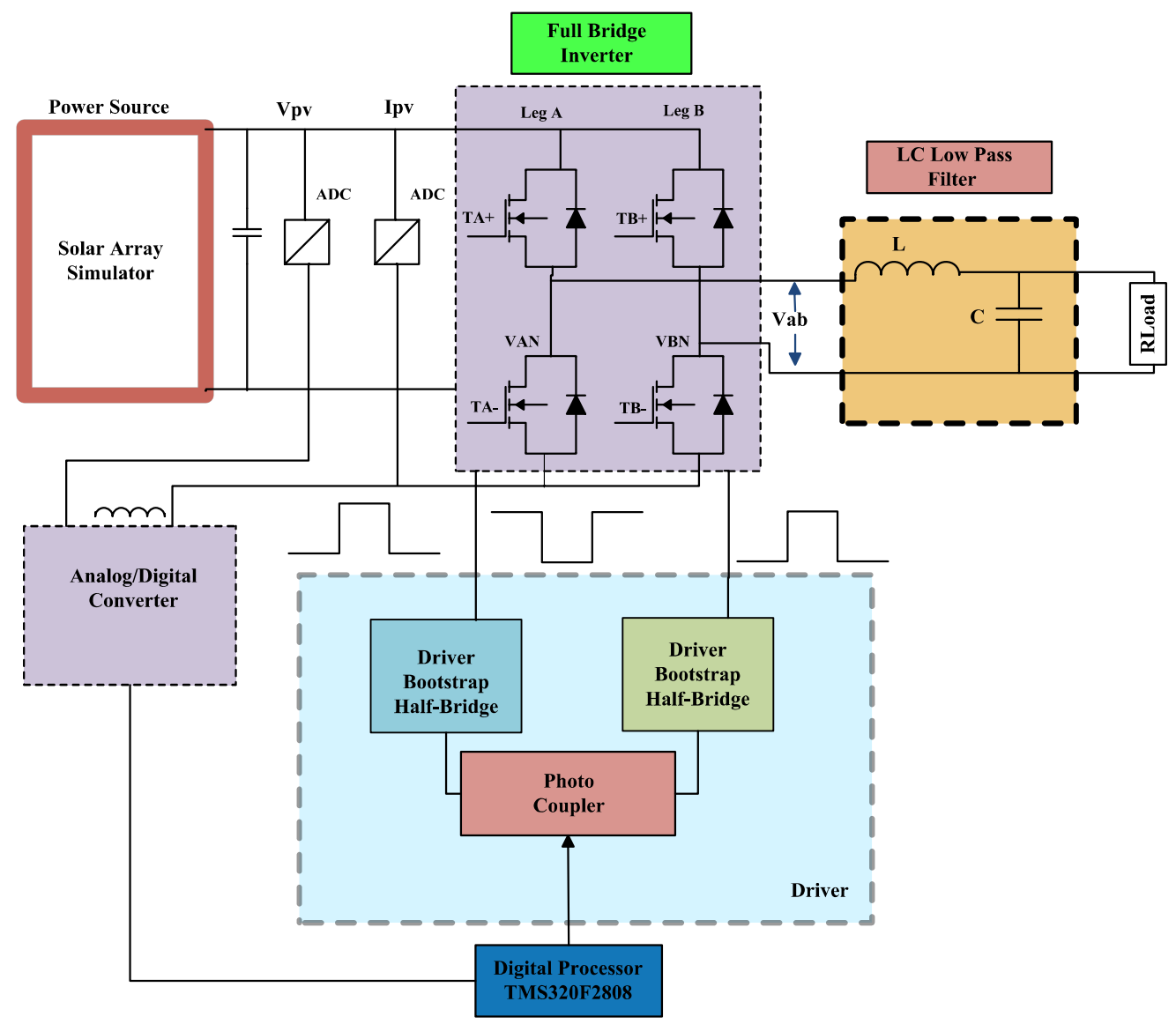

Figure 9. A full bridge inverter scheme with low pass filter and DSP controller for BRPVS.

The current swell is cut off to utilize the inductor. The value of the inductor is given by the following equations:

$$
\begin{gathered}
\mathrm{L}=\mathrm{V} \times \mathrm{di} / \mathrm{d} t \\
\mathrm{~L}=2 \times \mathrm{Vdc} \times \operatorname{Dmax} \Delta \operatorname{Imax} \times \mathrm{fs}
\end{gathered}
$$

where Vdc is the input DC voltage; fs is the switching frequency; $\mathrm{L}$ is the output filter inductor; $\triangle \mathrm{Imax}$ is the permissible ripple current and Dmax is the duty cycle maximum.

The capacitor depends on the inverter peak value and ripple voltage measurements of the output. Inductor current ripple is retained in the capacitor output. This can be shown in the following equation:

$$
\begin{gathered}
\Delta \text { Vout }=\Delta \mathrm{Vc} \\
\Delta \mathrm{Vc}_{\mathrm{c}} \cong \Delta \mathrm{I}_{\mathrm{Lc}} \times \mathrm{fs}+\mathrm{rESR} \times \Delta \mathrm{IL}
\end{gathered}
$$

where $\Delta$ Vout is the output voltage ripple; $\Delta \mathrm{I}_{\mathrm{Lc}}$ is the ripple current of the inductor and rESR is the capacitor equivalent series resistance.

\subsubsection{Energy Storage System (ESS)}

The variability and intermittency of the renewable energy sources within the renewable energy harnessing system can be mitigated to some extent while being integrated with the power grid. Residential dwellings and commercial buildings have a significant impact on the small-scale integration of renewable energy because of ESS. The storage technologies are not only for improving the levels of consumption from renewable energy sources, but also providing momentary benefit. 
The implementation of future intelligent grid technology, smart pricing, demand-side management, peak load, smart grid, demand-side management, smart metering, peak load curtailment, might deliver the goals of the regulator and policymakers but may also create uncertainty for consumers regarding the price of power. Power consumption control will be experienced by consumers when they purchase power and assess how much they consume during power shortages [7]. Therefore, a storage system is needed to save some energy when there is insufficient solar power available to run a specific load. During the charging process, the ESS available capacity at time, " $t$ " can be described as:

$$
\mathrm{E}_{\mathrm{ESS}}(t)=\mathrm{E}_{\mathrm{ESS}}(t-1)-\mathrm{E}_{\mathrm{CC}-\mathrm{OUT}}(t) \times \eta_{\mathrm{CHG}}
$$

The available ESS capacity during the discharging time can be given by Equation (28) [49].

$$
\operatorname{ESS}(t)=\mathrm{E}_{\mathrm{ESS}}(t-1)-\mathrm{E}_{\text {Needed }}(t)
$$

The depth of discharge (DoD) is a measure of how much energy has been withdrawn from a storage device, and is expressed as a percentage of the full capacity according to Equation (29).

$$
\mathrm{DOD}=(1-\mathrm{d}) \times 100
$$

The effective method of an energy management system that comprises storage elements allows consumers to shift their electricity purchases during peak hours to decrease the electricity demand

\section{Experimental Setup}

Figure 10 presents the experimental setup for a BRPVS system. To determine the effects of Al-BRS on temperature and power output, an experimental setup was developed, as shown in Figure 10a. The experiment was carried out near the Mechatronic Engineering Building 107 and the Laser and Sensor Laboratory, Pusan National University, having latitude $31.4861303^{\circ}$ E. The optimal tilt angle of $30^{\circ}$ was selected. A 20 watt PV module was used to determine the effects of reflector on the performance with the given latitude. A MASTECH MS827 millimeter for measuring current and voltage with different irradiance and reflector conditions. A FLUKE VT04A visual IR thermometer was utilized for thermal images at a specific time. An EL-USB-3 voltage and temperature data logger were used to measure the voltage and temperature of the PV module to recode the data.

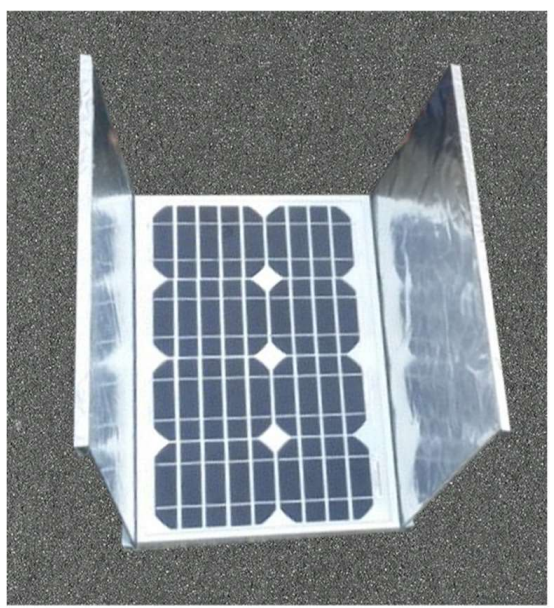

(a)

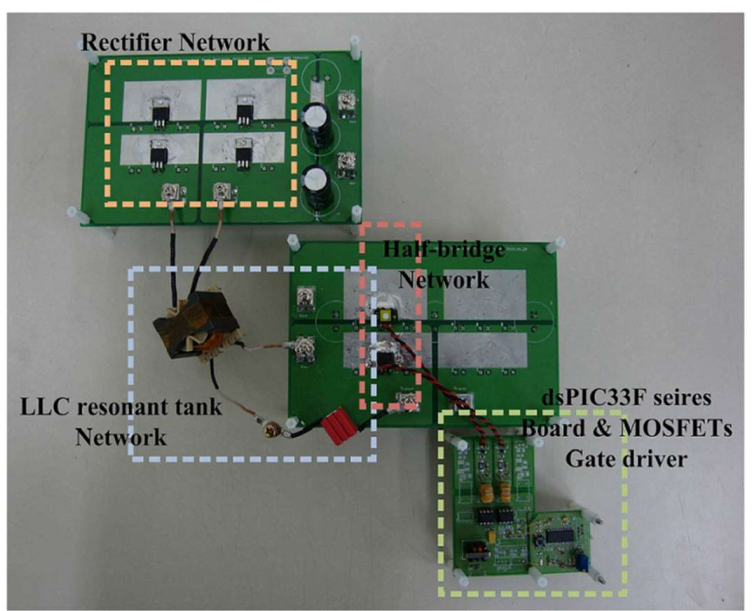

(b)

Figure 10. Experimental arrangements for (a) Al-foil based BRS; (b) Hardware implementation of 400 W Half bridge LLC converter prototype. 
A $0.5-\mathrm{mm}$ of thick aluminum foil sheet was wrapped on a paperboard of rectangular shape to make the structure firm. In the first experiment, aluminum foil was used as the equaling size as that of the solar cell. In the installation of the real-time BIPV system, the exact south $(180 \mathrm{~N})$ is not always available present so two different positions, south-east $150 \mathrm{~N}$ (diverted toward the east from south of $30^{\circ}$ ) and south-west $210 \mathrm{~N}$ (toward west diverted $30^{\circ}$ ), were used.

A 400-W prototype LLC converter was developed as shown in Figure 10b having an input voltage ranging 200-400 V and a fixed output voltage of $48 \mathrm{~V}$. A MASTECH MS8217 millimeter to get voltage and current value under various point. The LLC resonant converter control scheme has two different input voltage ranges according to the control scheme that depends upon PFM control scheme having input voltage from 200 to $300 \mathrm{~V}$ and by the asymmetric PWM at the input voltage range from 300 to $400 \mathrm{~V}$. The LLC resonant tank has 1.68 voltage gain with an input voltage $200 \mathrm{~V}$ and 1.12 voltage gain at input voltage $300 \mathrm{~V}$, where switching frequency varied from $50 \mathrm{kHz}$ to $112 \mathrm{kHz}$. Table 3 shows the LLC resonant converter design parameters. For the desired switching, the proposed hybrid switching scheme was used on a Microchip dsPIC33F16GS502.

Table 3. Specification of designed LCC converter for BRPVS.

\begin{tabular}{cc}
\hline Parameter & Value \\
\hline Maximum Power $\left(\mathrm{f}_{\max }\right)$ & $400 \mathrm{~W}$ \\
Switching Frequency $\left(\mathrm{f}_{\mathrm{s}}\right)$ & $60-112 \mathrm{kHz}$ \\
Input voltage range $\left(\mathrm{V}_{\mathrm{s}}\right)$ & $200-400 \mathrm{~V}$ \\
Series Resonant Capacitance $\left(\mathrm{C}_{\mathrm{r}}\right)$ & $66 \mathrm{nF}$ \\
Output voltage $\left(\mathrm{V}_{\mathrm{o}}\right)$ & $48 \mathrm{~V}$ \\
Series Resonant Inductance $\left(\mathrm{L}_{\mathrm{r}}\right)$ & $30.56 \mu \mathrm{H}$ \\
Parallel Resonant Inductance $\left(\mathrm{L}_{\mathrm{m}}\right)$ & $103.44 \mu \mathrm{H}$ \\
Turn Ratio of Transformer $\left(\mathrm{N}_{\mathrm{p}}: \mathrm{N}_{\mathrm{s}}\right)$ & $24: 7$ \\
Input Capacitance $\left(\mathrm{C}_{\mathrm{in}}\right)$ & $450 \mathrm{~V} / 330 \mu \mathrm{F}$ \\
Output Capacitance $\left(\mathrm{C}_{\mathrm{o}}\right)$ & $200 \mathrm{~V} / 220 \mu \mathrm{F}$ \\
\hline
\end{tabular}

\section{Results and Discussion}

Outdoor testing of the BRPVS was performed at Busan $\left(35^{\circ} 10^{\prime} 0^{\prime \prime} \mathrm{N}, 129^{\circ} 4^{\prime} 0^{\prime \prime} \mathrm{E}\right)$, South Korea. The Korean Metrological Agency (KMA) was used as a source of authentic data for expected Busan weather conditions, to investigate the effect of BRPVS on the efficiency of PV system of solar PV module. The data of the solar insolation were provided in $\mathrm{MJ} / \mathrm{m}^{2}$, which was then converted for compatibility and simplicity to $\mathrm{kW} / \mathrm{m}^{2}$. Solar insolation for twelve days randomly selected days was considered, exactly one day for each month having sunny weather from morning to evening, as shown in Figure 11. The data showed that the solar irradiance was very low in cold weather: smaller than $1 \mathrm{~kW} / \mathrm{m}^{2}$ from morning 7:00 to 1:00 (Figure 11a) and evening from 3:00 pm to 6:00 pm (Figure 11c). During December, January, and February, and maximum solar insulation was $0.63 \mathrm{~kW} / \mathrm{m}^{2}$ at the afternoon from 11:00 to 2:00 pm (Figure 11b). The maximum solar irradiance from March to May was $0.70 \mathrm{kWh} / \mathrm{m}^{2}$. Compared to the STC $\left(1 \mathrm{~kW} / \mathrm{m}^{2}\right)$ for the solar panel, this is still very low. Value incremented to $0.95 \mathrm{kWh} / \mathrm{m}^{2}$ in summer but it could not generate electricity at full capacity because of the increase in temperature of the solar panels. The variation of irradiance throughout the year from morning and evening shown in Figure 11 was much lower than the STC. The data in Figure 11 supports the importance of the reflector system because output power will increase as the amount of incident light increases in the solar panel. 


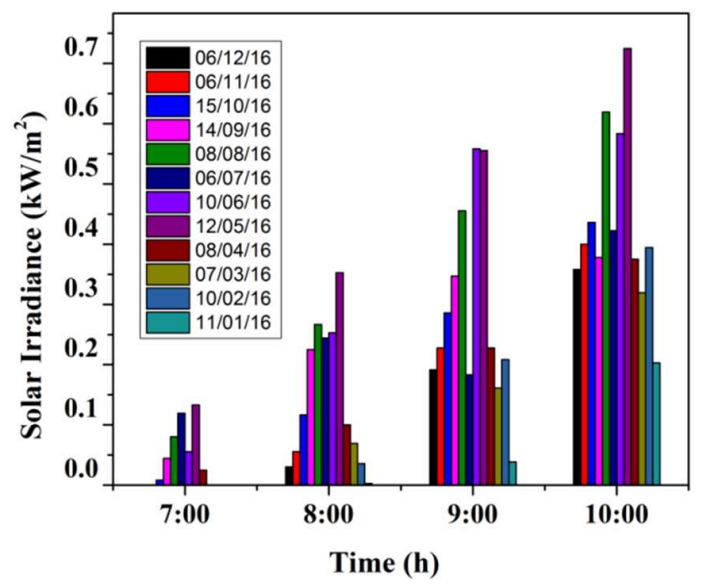

(a)

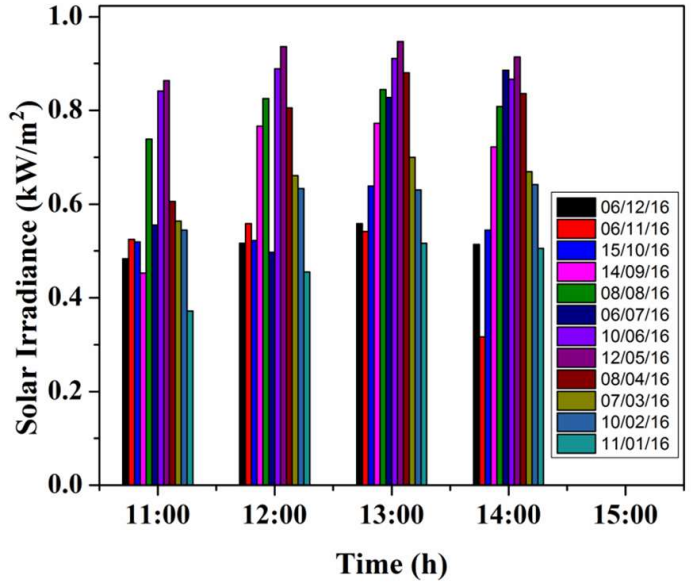

(b)

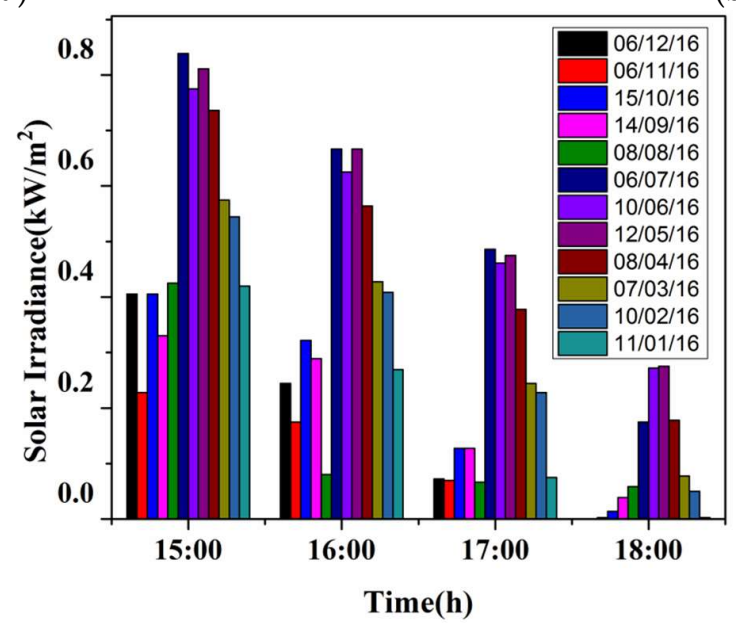

(c)

Figure 11. Solar irradiance of Busan $\left(35^{\circ} 10^{\prime} 0^{\prime \prime} \mathrm{N}, 129^{\circ} 4^{\prime} 0^{\prime \prime} \mathrm{E}\right)$ : (a) Morning (7:00 to 10:00); (b) Afternoon (11:00 to 14:00); (c) Evening (15:00 to 18:00).

\subsection{Investigating Effectiveness of BRPVS}

Effect of BRPVS with an Al-foil sheet on the output power of the solar PV module having a 20-W capacity, placed at $0^{\circ}$ south was noticed. The data was examined for a time period from 8:30 to 16:30. Figure 12 show voltage of the open circuit $\left(\mathrm{V}_{\mathrm{oc}}\right)$, short circuit current $\left(\mathrm{I}_{\mathrm{sh}}\right)$ and output power. Figure 12a indicates that from 8:30 am to $4: 00 \mathrm{pm}$, the $V_{\text {oc }}$ was maintained on specific value but when the intensity of sunlight decreased, there was a sudden dip in voltage of the open circuit. On the other hand, the current varies with time, i.e., it increases, specifically from $0.67 \mathrm{~A}$ to $1.2 \mathrm{~A}$ for some time from 8:30 to 16:30 and decreases slowly from 12:00 to 16:30.

The performance comparison was made by comparing the output power of the Al-foil sheet reflector with a panel without a reflector. Significant improvement in the result was obtained while using the reflector. Using Al-Foil BRS produces an output of $20.31 \mathrm{~W}$, while without a reflector, it is only $16.84 \mathrm{~W}$. 


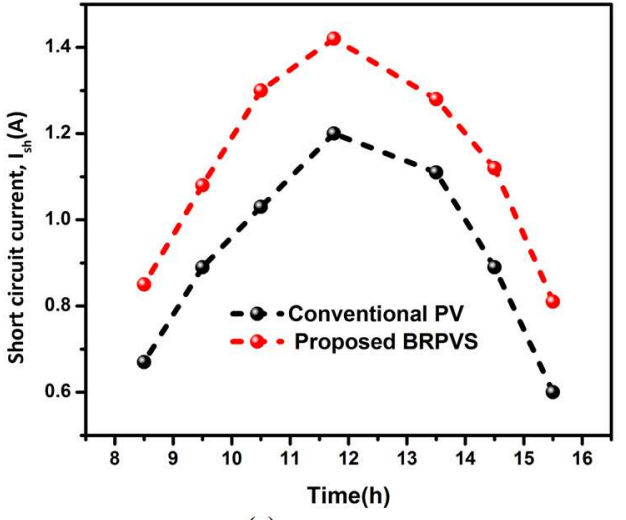

(a)

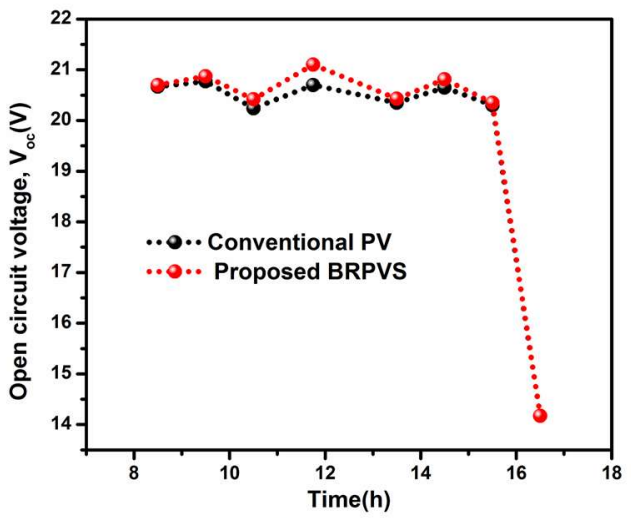

(b)

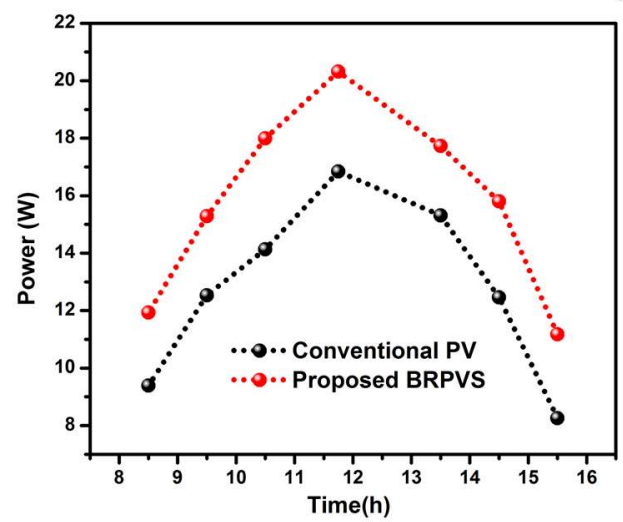

(c)

Figure 12. Comparative analysis of the (a) Short circuit current (Ish); (b) Open circuit voltage $\left(\mathrm{V}_{\mathrm{oc}}\right)$; (c) Output power of BIPV system with and without Al foil based BRPVS.

The use of Al-foil reflector does not too much increase the cost of the PV system but improves its effectiveness. The temperature effect on Al-BRS was then monitored. During the experiment, the thermal images were photographed for the PV module with the BRPVS system.

In Figure 13, the thermal image showed a temperature hotspot at 11:30, 12:30, and 13:30 with no reflectors at $42.1{ }^{\circ} \mathrm{C}, 42.3^{\circ} \mathrm{C}$, and $43^{\circ} \mathrm{C}$, respectively. Conversely, at 11:30, 12:30, and 13:30 using the Al-Foil reflector, the hotspot temperatures for the solar power system were $38.9^{\circ} \mathrm{C}, 39.4{ }^{\circ} \mathrm{C}$ and $40.5^{\circ} \mathrm{C}$, respectively. The above statistics show that using a reflector ensures that the PV system is safe and does not significantly increase the temperature of the BIPV system.
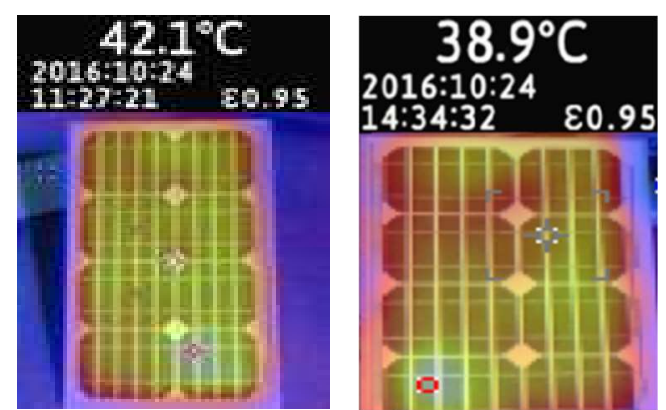

(a)

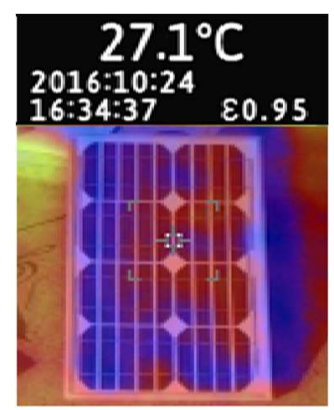

Figure 13. Cont. 

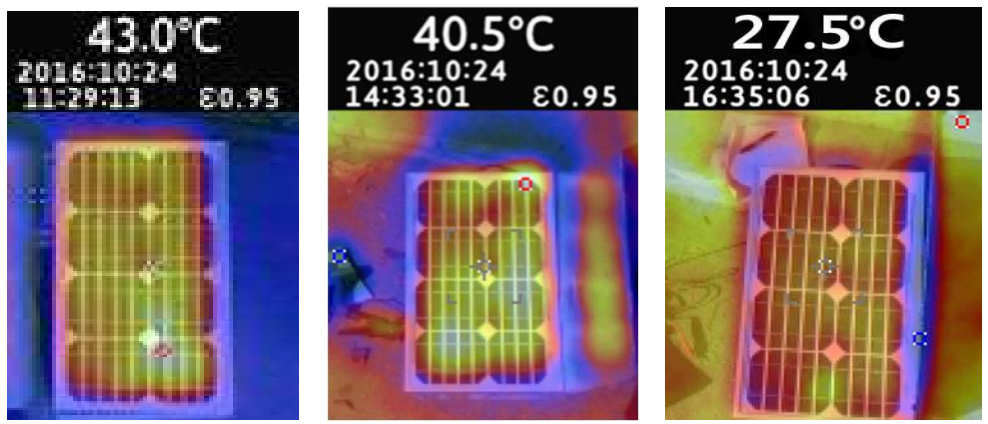

(b)

Figure 13. Studying effect on temperature of PV module (a) Without BRS; (b) Al foil BRS.

\subsection{Al-Foil Reflector Optimal Size and Position for BRPVS}

Al-foil has significant effects on the PV system output power. Moreover, it is quite inexpensive. The efficiency depends mostly on the size of the aluminum foil reflector. Different experiments were conducted with different sizes of $\mathrm{Al}$ foil as a reflector to determine the optimal size of the $\mathrm{Al}$ foil (Figure 14). The positions of the PV system in the solar panel were placed at South $0^{\circ}$ (North $180^{\circ}$ ) with a tilt angle of $30^{\circ}$. Three different sizes of $\mathrm{Al}$ foil were selected: $1 / 3$ (length $=54 \mathrm{~cm}$ width $=12 \mathrm{~cm}$ ), $2 / 3(54 \mathrm{~cm}$ width $=24 \mathrm{~cm})$, and equal to the size of the solar panel. The output power of the solar $\mathrm{PV}$ module increased from $7.62 \%$ to $9.11 \%$ when the $\mathrm{Al}$ foil size was one-third of the solar panel (Figure 14a,b). The output power improved $16.05-17.57 \%$ when $\mathrm{Al}$ foil 2/3 of the solar panel size was used. The output power was increased $25.92-28.47 \%$ when the size of reflector was equal to the size of the panel. This shows that the output power increases with increasing size of the reflector.

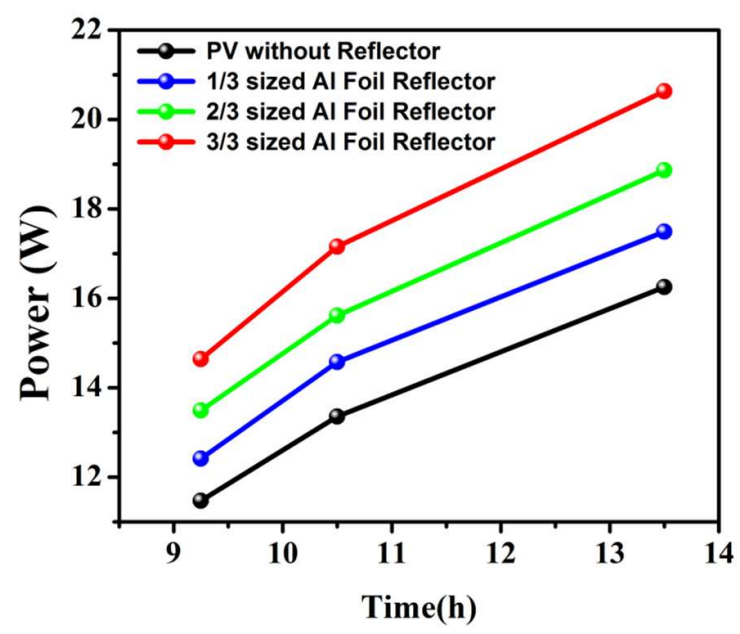

(a)

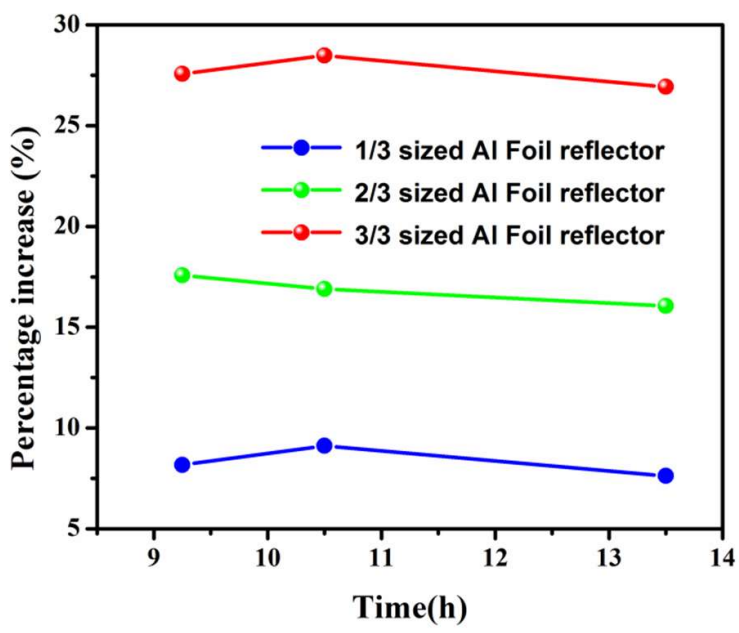

(b)

Figure 14. Finding optimal size of reflector: (a) Output power; (b)Percentage increase.

The next task was to find the optimal angle for BRPVS that gives the highest output power. Perfect south is difficult to achieve for every BIPV system. Hence, three different positions were selected: south $0^{\circ}$, south-east $\left(30^{\circ}\right.$ from south towards east), and south west ( $30^{\circ}$ from south towards west).

Figure 15 shows the output power of the solar module while using the Al-Foil BRS with the above-mentioned angles. The optical angle of BRS differs depending on position and time. The optimal BRS angles for the south, south-east, and south-west locations from 9:00 am to 11:00 am were 80 $75^{\circ}$ and $90^{\circ}$, respectively (Figure 15a-c). During the afternoon time i.e., 11:00 am to 2:00 pm keeping both reflectors at $90^{\circ}$ delivers maximum output power. In the evening from 3:00 pm to 5:00 pm, 
the best angle for the south, south-east, and south-west position was $80^{\circ}, 90^{\circ}$, and $75^{\circ}$, respectively. These results show as panel move for south the optimal angle for BRS changes however with little adjustment in the reflector angle can help to yield more power from the same module without reflector

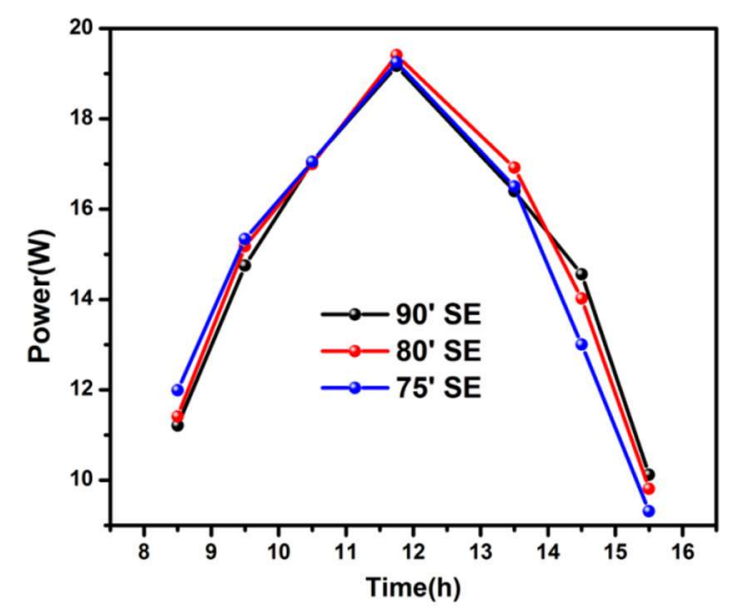

(a)

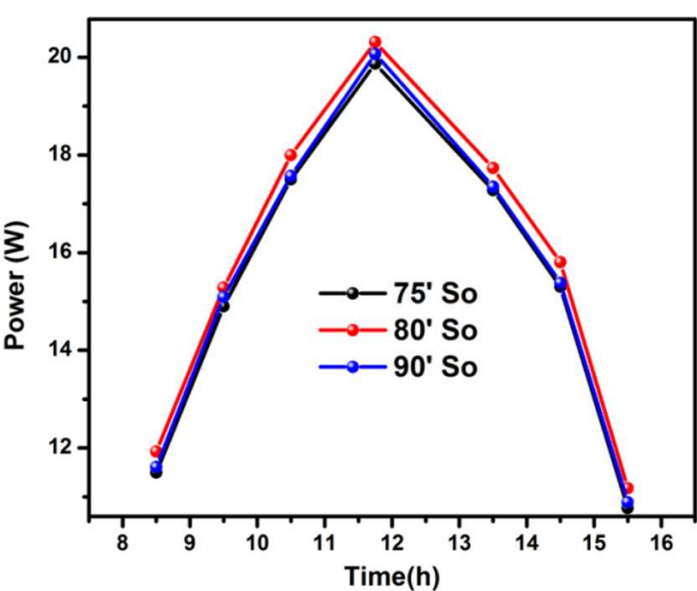

(b)

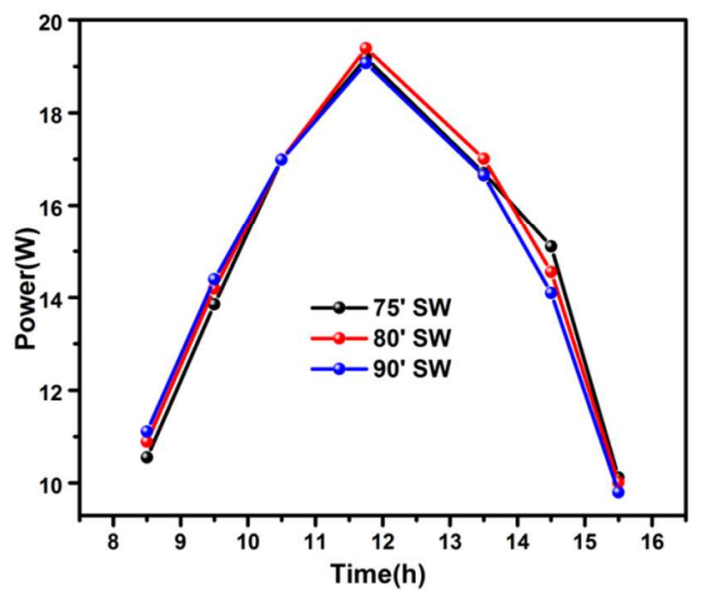

(c)

Figure 15. Output power of PV (a) south $0^{\circ}$; (b) south-east ( $30^{\circ}$ from south towards east);(c) south-west $\left(30^{\circ}\right.$ from south towards west).

\subsection{Performance Evaluation of Designed Half Bridge LLC Converter}

The 400-W LLC converter for wide range voltage variations was designed as discussed in Section 2.2.1, and the experimental setup was developed based on the parameters discussed in Section 3. Figure 16 shows the waveform of a half-bridge LLC resonant converter for the desired experimental study. Variable input voltages of 200-400 V with variable switching frequencies were considered for the analysis. The switching was performed at high frequencies ranging from $90.23 \mathrm{kHz}$ to $110 \mathrm{kHz}$ to reduce the size of the transformer. Figure 16 shows waveform for $200 \mathrm{~V}$ input with switching frequency $74.67 \mathrm{kHz}$. Figure 13a,b shows the waveforms for voltage $200 \mathrm{~V}, 230 \mathrm{~V}$ while Figure $13 \mathrm{c}$,d represents $300 \mathrm{~V}$ and $400 \mathrm{~V}$, respectively. 


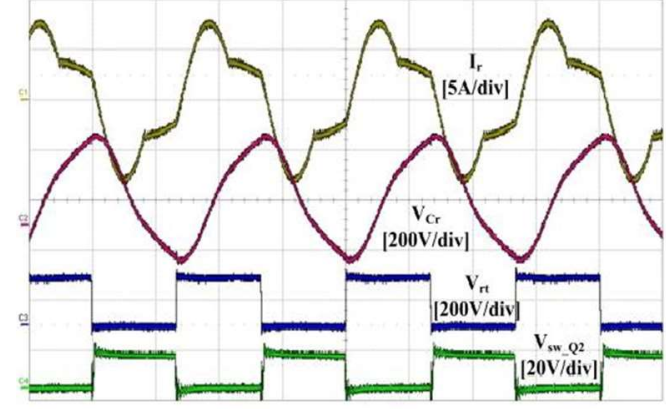

(a)

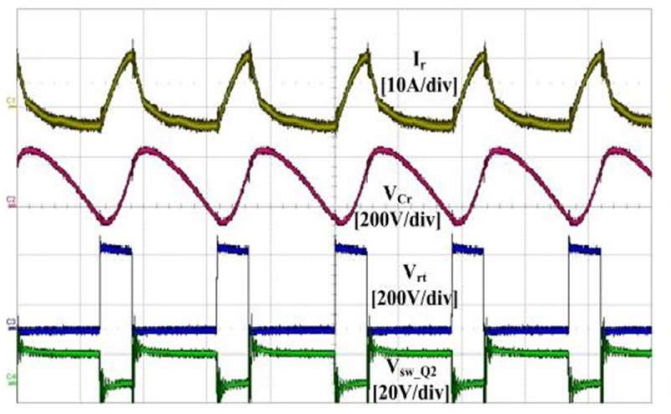

(c)

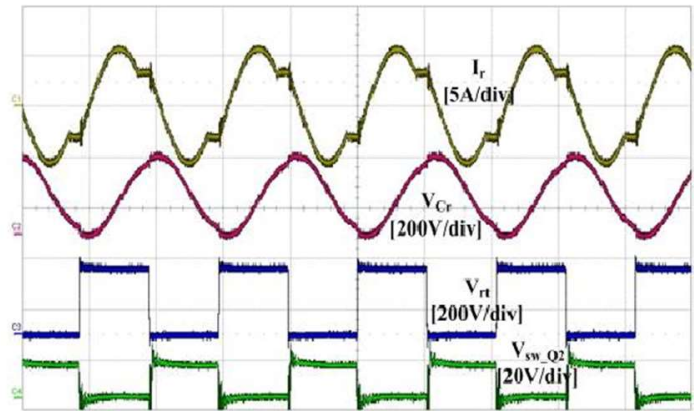

(b)

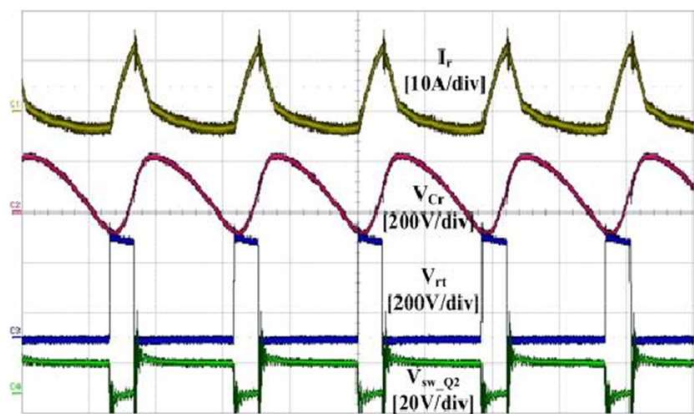

(d)

Figure 16. Testing operation of designed converter for wide range variable input voltage. $(\mathbf{a}) \mathrm{V}_{\text {in }}=200 \mathrm{~V}$, $\mathrm{f}_{\mathrm{s}}=74.67 \mathrm{kHz} ;(\mathbf{b}) \mathrm{V}_{\text {in }}=230 \mathrm{~V}, \mathrm{f}_{\mathrm{s}}=82.31 \mathrm{kHz} ;(\mathbf{c}) \mathrm{V}_{\text {in }}=300 \mathrm{~V}, \mathrm{f}_{\mathrm{s}}=109.23 \mathrm{kHz} ;(\mathbf{d}) \mathrm{V}_{\text {in }}=400 \mathrm{~V}, \mathrm{f}_{\mathrm{s}}=109.23 \mathrm{kHz}$.

Figure 16a shows the current of the resonant inductor $\left(\mathrm{I}_{\mathrm{r}}\right)$, resonant voltage $\left(\mathrm{V}_{\mathrm{r}}\right)$, and input voltage $\left(\mathrm{V}_{\text {in }}\right)$ of the LLC resonant tank and switching signal of $\mathrm{Q} 2$ at an input voltage of $200 \mathrm{~V}$. The red line in the graph presents the output voltage while the blue line shows the input voltage. Similarly, the yellow and green input voltage $\left(\mathrm{V}_{\text {in }}\right)$ and switching signal of $\mathrm{Q} 2$ are shown. The output voltage was controlled and kept constant at $48 \mathrm{~V}$. The results clearly show that the switching frequency increased with increasing input voltage in order to regulate the output voltage in the PFM operation region. In addition, resonance current peak value enlarged due to the increase in amount of current circulating in the resonant tank.

\section{Conclusions}

The power generation performance of the BIPV is influenced by the amount the of available solar radiation. The output power given by photovoltaic systems increases in proportion to the solar radiation. This study confirmed the effect of BRPVS on the performance of BIPV module through real-time outdoor experiments. Half-bridge LLC resonant converters for wide input range voltage fluctuations (200-400 V) and medium power applications have been proposed and tested by experiments using a 400-W prototype. Experimental results show that using a low-cost $\mathrm{Al}$ foil reflector in a BRPVS system can improve the output power by more than $28.47 \%$ depending on the time, size of the reflector, and location of the solar panel. Movement of BRPVS was controlled by the algorithm developed and discussed in this paper. A hardware implementation of the algorithm was performed using an Arduino-controlled CdS sensor and a stepper motor array. A BRPVS solar system was found to be a cost-effective solution for BIPV with conventional amorphous and crystalline solar panels and can be applied easily for future zero carbon green energy buildings, particularly in countries with lower annual solar radiation than the standard test condition defined for a solar PV system or building where it is difficult to face the PV panels completely towards south or the Sun. Future research should evaluate efficient reflector materials and effective control system operating mechanisms. 
Author Contributions: H.-J.K. and M.A.K. conceptualize the idea of this research work. H.-J.K developed the proposal to the funding body. M.A.K. designed the experimental setup and procured the equipment and the material required for the experimental work. The fabrication and integration of the experimental setup was mostly carried out by the M.A.K. and S.H. under the supervision of H.-J.K., P.S., A.S., S.H. and H. helped in experimental work and fabrication of power conversion circuit. Results were analyzed by K.Z., M.U.A., W.U. and M.I. The paper was written by all the authors with different degrees of contribution.

Acknowledgments: This research was supported by Basic Research Laboratory through the National Research Foundations of Korea funded by the Ministry of Science, ICT and Future Planning (NRF-2015R1A4A1041584).

Conflicts of Interest: The authors declare no conflict of interest.

\section{References}

1. Liu, X.; Wu, Y.; Hou, X.; Liu, H. Investigation of the Optical Performance of a Novel Planar Static PV Concentrator with Lambertian Rear Reflectors. Buildings 2017, 7, 88. [CrossRef]

2. Tahir, S.; Wang, J.; Baloch, M.H.; Kaloi, G.S. Digital Control Techniques Based on Voltage Source Inverters in Renewable Energy Applications: A Review. Electronics 2018, 7, 18. [CrossRef]

3. Norton, B.; Eames, P.C.; Mallick, T.K.; Huang, M.J.; McCormack, S.J.; Mondol, J.D.; Yohanis, Y.G. Enhancing the performance of building integrated photovoltaics. Sol. Energy 2011, 85, 1629-1664. [CrossRef]

4. Öztürk, S.; Canver, M.; Çadırcı, I.; Ermiş, M. All SiC Grid-Connected PV Supply with HF Link MPPT Converter: System Design Methodology and Development of a 20 kHz, 25 kVA Prototype. Electronics 2018, 7, 85. [CrossRef]

5. Tian, H.; Yu, X.; Zhang, J.; Duan, W.; Tian, F.; Yu, T. The influence of environmental factors on DSSCs for BIPV. Int. J. Electrochem. Sci. 2012, 7, 4686-4691.

6. Mousazadeh, H.; Keyhani, A.; Javadi, A.; Mobli, H.; Abrinia, K.; Sharifi, A. A review of principle and sun-tracking methods for maximizing solar systems output. Renew. Sustain. Energy Rev. 2009, 13, 1800-1818. [CrossRef]

7. Yaden, M.F.; Melhaoui, M.; Gaamouche, R.; Hirech, K.; Baghaz, E.; Kassmi, K. Photovoltaic System Equipped with Digital Command Control and Acquisition. Electronics 2013, 2, 192-211. [CrossRef]

8. Hafez, A.Z.; Yousef, A.M.; Harag, N.M. Solar tracking systems: Technologies and trackers drive types-A review. Renew. Sustain. Energy Rev. 2018, 91, 754-782. [CrossRef]

9. Vračar, L.; Prijić, A.; Nešić, D.; Dević, S.; Prijić, Z. Photovoltaic Energy Harvesting Wireless Sensor Node for Telemetry Applications Optimized for Low Illumination Levels. Electronics 2016, 5, 26. [CrossRef]

10. Khan, M.A.; Zeb, K.; Sathishkumar, P.; Ali, M.U.; Uddin, W.; Hussain, S.; Ishfaq, M.; Khan, I.; Cho, H.-G.; Kim, H.-J. A Novel Supercapacitor/Lithium-Ion Hybrid Energy System with a Fuzzy Logic-Controlled Fast Charging and Intelligent Energy Management System. Electronics 2018, 7, 63. [CrossRef]

11. Chemisana, D. Building integrated concentrating photovoltaics: A review. Renew. Sustain. Energy Rev. 2011, 15, 603-611. [CrossRef]

12. Yoon, S.; Tak, S.; Kim, J.; Jun, Y.; Kang, K.; Park, J. Application of transparent dye-sensitized solar cells to building integrated photovoltaic systems. Build. Environ. 2011, 46, 1899-1904. [CrossRef]

13. French, R.H.; Murray, M.P.; Lin, W.C.; Shell, K.A.; Brown, S.A.; Schuetz, M.A.; Davis, R.J. Solar radiation durability of materials components and systems for low concentration photovoltaic systems. In Proceedings of the IEEE Energytech, Cleveland, OH, USA, 25-26 May 2011; pp. 1-5.

14. Probst, M.M.; Roecker, C. Towards an improved architectural quality of building integrated solar thermal systems (BIST). Sol. Energy 2007, 81, 1104-1116. [CrossRef]

15. Augustin, D.; Chacko, R.; Jacob, J. Canal top solar PV with reflectors. In Proceedings of the 2016 IEEE International Conference on Power Electronics, Drives and Energy Systems (PEDES), Trivandrum, India, 14-17 December 2016; pp. 1-5.

16. Karlsson, B.; Wilson, G. MaReCo design for horizontal, vertical or tilted installation. In Proceedings of the EuroSun, Copenhagen, Denmark, 19-22 June 2000.

17. Brogren, M.; Karlsson, B. Low-concentrating water-cooled PV thermal hybrid systems for high latitudes. In Proceedings of the Conference Record of the Twenty-Ninth IEEE Photovoltaic Specialists Conference, New Orleans, LA, USA, 19-24 May 2002; pp. 1733-1736.

18. Dubey, S.; Tiwari, G.N. Thermal modeling of a combined system of photovoltaic thermal (PV/T) solar water heater. Sol. Energy 2008, 82, 602-612. [CrossRef] 
19. Anderson, T.N.; Duke, M.; Morrison, G.L.; Carson, J.K. Performance of a building integrated photovoltaic/thermal (BIPVT) solar collector. Sol. Energy 2009, 83, 445-455. [CrossRef]

20. Baitule, A.S.; Sudhakar, K. Solar powered green campus: a simulation study. Int. J. Low-Carbon Technol. 2017, 12, 400-410. [CrossRef]

21. Tien, N.X.; Shin, S. A Novel Concentrator Photovoltaic (CPV) System with the Improvement of Irradiance Uniformity and the Capturing of Diffuse Solar Radiation. Appl. Sci. 2016, 6, 251. [CrossRef]

22. Pérez-Higueras, P.; Muñoz, E.; Almonacid, G.; Vidal, P.G. High concentrator photovoltaics efficiencies: Present status and forecast. Renew. Sustain. Energy Rev. 2011, 15, 1810-1815. [CrossRef]

23. Kosti, L.T.; Pavlovi, Z.T. Optimal position of flat plate reflectors of solar thermal collector. Energy Build. 2012, 45, 161-168. [CrossRef]

24. Pucar, M.D.J.; Despic, A.R. The enhancement of energy gain of solar collectors and photovoltaic panels by the reflection of solar beams. Energy 2002, 27, 205-223. [CrossRef]

25. Hall, M.; Roos, A.; Karlsson, B. Reflector materials for two-dimensional low-concentrating photovoltaic systems: The effect of specular versus diffuse reflectance on the module efficiency. Prog. Photovolt. Res. Appl. 2005, 13, 217-233. [CrossRef]

26. Grassie, S.L.; Sheridan, N.R. The use of planar reflectors for increasing the energy yield of flat-plate collectors. Sol. Energy 1977, 19, 663-668. [CrossRef]

27. Tina, G.M.; Ventura, C. Energy assessment of enhanced fixed low concentration photovoltaic systems. Sol. Energy 2015, 119, 68-82. [CrossRef]

28. Lin, W.C.; Hollingshead, D.; French, R.H.; Shell, K.A.; Schuetz, M.; Karas, J. Non-tracked mirror-augmented photovoltaic design and performance. In Proceedings of the 38th IEEE Photovoltaic Specialists Conference (PVSC), Austin, TX, USA, 3-8 June 2012; pp. 2076-2081.

29. Van Dijk, L.; van de Groep, J.; Veldhuizen, L.W.; Di Vece, M.; Schropp, R.E.I. Concepts for external light trapping and its utilization in colored and image displaying photovoltaic modules. Prog. Photovolt. Res. Appl. 2017, 25, 553-568. [CrossRef]

30. Matsushima, T.; Setaka, T.; Muroyama, S. Concentrating solar module with horizontal reflectors. Sol. Energy Mater. Sol. Cells 2003, 75, 603-612. [CrossRef]

31. Khan, M.A.; Ko, B.; Alois Nyari, E.; Park, S.E.; Kim, H.-J. Performance Evaluation of Photovoltaic Solar System with Different Cooling Methods and a Bi-Reflector PV System (BRPVS): An Experimental Study and Comparative Analysis. Energies 2017, 10, 826. [CrossRef]

32. Filippini, M.; Molinas, M.; Oregi, E.O. A Flexible Power Electronics Configuration for Coupling Renewable Energy Sources. Electronics 2015, 4, 283-302. [CrossRef]

33. Sathishkumar, P.; Krishna, T.N.V.; Himanshu; Khan, M.A.; Zeb, K.; Kim, H.-J. Digital Soft Start Implementation for Minimizing Start Up Transients in High Power DAB-IBDC Converter. Energies 2018, 11, 956. [CrossRef]

34. Khan, M.A.; Krishna, T.N.V.; Sathishkumar, P.; Sarat, G.; Kim, H.-J. A hybrid power supply with fuzzy controlled fast charging strategy for mobile robots. In Proceedings of the International Conference on Information and Communication Technology Robotics (ICT-ROBOT 2016), Busan, Korea, 7-9 September 2016.

35. Khan, M.A.; Badshah, S. Design and analysis of cross flow turbine for micro hydro power application using sewerage water. RJASET 2014, 8, 821-828. [CrossRef]

36. Popavath, L.N.; Kaliannan, P. Photovoltaic-STATCOM with Low Voltage Ride through Strategy and Power Quality Enhancement in a Grid Integrated Wind-PV System. Electronics 2018, 7, 51. [CrossRef]

37. Moonem, M.A.; Pechacek, C.L.; Hernandez, R.; Krishnaswami, H. Analysis of a Multilevel Dual Active Bridge (ML-DAB) DC-DC Converter Using Symmetric Modulation. Electronics 2015, 4, 239-260. [CrossRef]

38. Buccella, C.; Cecati, C.; Latafat, H.; Razi, K. A grid-connected PV system with LLC resonant DC-DC converter. In Proceedings of the International Conference on Clean Electrical Power (ICCEP), Alghero, Italy, 11-13 June 2013.

39. Beiranvand, R.; Rashidian, B.; Zolghadri, M.R.; Alavi, S.M.H. Using LLC resonant converter for designing wide-range voltage source. IEEE Trans. Ind. Electron. 2011, 58, 1746-1756. [CrossRef]

40. Chang, C.H.; Chang, E.C.; Cheng, H.L. A high-efficiency solar array simulator implemented by an LLC resonant DC-DC converter. IEEE Trans. Ind. Electron. 2013, 28, 3039-3046. [CrossRef]

41. Mishima, T.; Nakaoka, M. A novel high-frequency transformer-linked soft-switching half-bridge DC-DC converter with constant-frequency asymmetrical PWM scheme. IEEE Trans. Ind. Electron. 2009, 56, 2961-2969. [CrossRef] 
42. Jang, J.; Pidaparthy, S.K.; Choi, B. Current Mode Control for LLC Series Resonant DC-to-DC Converters. Energies 2015, 8, 6098-6113. [CrossRef]

43. Shin, D.; Lee, K.J.; Lee, J.P.; Kim, H.J. Hybrid Control Scheme for a Half-Bridge LLC Resonant Converter with a Wide Input Range. In Proceedings of the International Conference on Intelligent Robotics and Applications, Busan, Korea, 25-28 September 2013; pp. 345-352.

44. Feng, W.; Lee, F.C.; Mattavelli, P. A hybrid strategy with simplified optimal trajectory control for LLC resonant converters. In Proceedings of the Twenty-Seventh Annual IEEE Applied Power Electronics Conference and Exposition (APEC), Orlando, FL, USA, 5-9 February 2012; pp. 1096-1103.

45. The Facets about Aluminum. Available online: http://www.alufoil.org/facts.html (accessed on 24 July 2017).

46. Stutenbaeumer, U.; Mesfin, B. Equivalent model of monocrystalline, polycrystalline and amorphous silicon solar cells. Renew. Energy 1999, 18, 501-512. [CrossRef]

47. Bahaidarah, H.M.; Tanweer, B.; Gandhidasan, P.; Rehman, S. A Combined optical, thermal and electrical performance study of a V-trough PV System-Experimental and analytical investigations. Energies 2015, 8, 2803-2827. [CrossRef]

48. Andrews, R.W.; Pollard, A.; Pearce, J.P. Photovoltaic system performance enhancement with nontracking planar concentrators: Experimental results and bidirectional reflectance function (BDRF)-based modeling. In Proceedings of the IEEE 39th Photovoltaic Specialists Conference (PVSC), Tampa, FL, USA, 16-21 June 2013; pp. 229-234.

49. Khan, M.A.; Zeb, K.; Sathishkumar, P.; Himanshu; Rao, S.S.; Gopi, C.V.V.M.; Kim, H.-J. A Novel Off-Grid Optimal Hybrid Energy System for Rural Electrification of Tanzania Using a Closed Loop Cooled Solar System. Energies 2018, 11, 905. [CrossRef]

(C) 2018 by the authors. Licensee MDPI, Basel, Switzerland. This article is an open access article distributed under the terms and conditions of the Creative Commons Attribution (CC BY) license (http:/ / creativecommons.org/licenses/by/4.0/). 